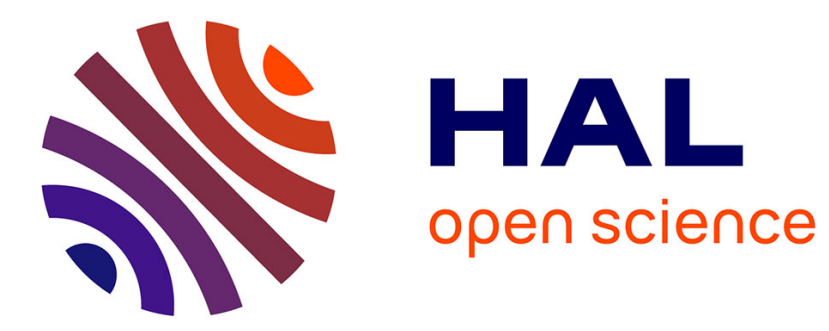

\title{
Early Middle Paleozoic Intraplate Orogeny in the Ogcheon Belt (South Korea): A new insight on the Paleozoic buildup of east Asia
}

Dominique Cluzel, Laurent Jolivet, Jean-Paul Cadet

\section{- To cite this version:}

Dominique Cluzel, Laurent Jolivet, Jean-Paul Cadet. Early Middle Paleozoic Intraplate Orogeny in the Ogcheon Belt (South Korea): A new insight on the Paleozoic buildup of east Asia. Tectonics, 1991, 10 (6), pp.1130-1151. 10.1029/91TC00866 . insu-00726564

HAL Id: insu-00726564

https://hal-insu.archives-ouvertes.fr/insu-00726564

Submitted on 30 Aug 2012

HAL is a multi-disciplinary open access archive for the deposit and dissemination of scientific research documents, whether they are published or not. The documents may come from teaching and research institutions in France or abroad, or from public or private research centers.
L'archive ouverte pluridisciplinaire HAL, est destinée au dépôt et à la diffusion de documents scientifiques de niveau recherche, publiés ou non, émanant des établissements d'enseignement et de recherche français ou étrangers, des laboratoires publics ou privés. 
TECTONICS, VOL. 10, NO. 6, PAGES 1130-1151, DECEMBER 1991

\section{EARLY MIDDLE PALEOZOIC INTRAPLATE OROGENY IN THE OGCHEON BELT (SOUTH KOREA): A NEW INSIGHT ON THE PALEOZOIC BUILDUP OF EAST ASIA}

\author{
Dominique Cluzel \\ Laboratoire de Géologie Structurale, Université d'Orléans, \\ Orléans, France \\ Laurent Jolivet \\ Laboratoire de Géologie, Ecole Normale Supérieure, Paris, \\ France \\ Jean-Paul Cadet \\ Département de Géotectonique, Université Pierre et Marie \\ Curie, Paris, France
}

\begin{abstract}
The polycyclic Ogcheon belt of South Korea represents the boundary between two Precambrian blocks. Investigation on the timing and kinematics of the block agglomeration is of considerable bearing on the understanding of the constitution of the Asian continent. We report here structural evidence showing that the earlier tectonic event dates back to early middle Paleozoic (the "Ogcheon tectonism" or "orogeny"). The ductile piling up of nappes of the Ogcheon belt corresponds to an intracontinental orogeny involving the opening and the subsequent closure of an aborted rift and not of a wide oceanic area. The nappes contain unequivocal evidence for ductile shearing with a northwest over southeast sense of movement. Field evidence includes the presence of S1 and S1-2 foliations bearing an extensive stretching lineation perpendicular to the belt, associated with a strongly noncoaxial deformation regime.The $F 1$ isoclinal folds are commonly "A type" and sheath folds whose axes are parallel to the stretching lineation, whereas the southeast facing F2 recumbent folds have subhorizontal axes parallel to the belt. All lines of evidence (unconformity, superposed deformations, age of the metamorphism, etc...) imply that the D1-2 "Ogcheon tectonism" is pre-middle Carboniferous (Late Silurian-Early Devonian). The subsequent Indosinian (Middle Triassic) F3 upright synfolial folds that trend NNE-SSW and later structures clearly overprint the middle Paleozoic ductile thrusts and isoclinal folds. The early Paleozoic Ogcheon Supergroup is formed of a thick volcanosedimentary pile deposited above an early platform sequence in a rift basin. On the basis of the geochemical characteristics of the metavolcanics, it appears that oceanization did not occur and Ogcheon rift aborted soon after it was formed. We suggest that middle Palcozoic ductile nappe structures have been formed by the structural inversion of the rift extensional features. During the ductile stacking episode, the early formed foliation and isoclinal folds have been folded in a continuum during the same tectonic event. Middle Carboniferous terrigenous formations have been deposited unconformably upon folded and thrust older rocks. A tentative correlation with early Paleozoic Imjingang, Qinling and Cathaysian belts within the Asian continent reveals that Ogcheon rift was emplaced within the South China plate and that Imjingang belt should represent the limit between North and South China blocks in the Korean peninsula.
\end{abstract}

Copyright 1991 by the American Geophysical Union.

Paper number $91 \mathrm{TC} 00866$.

(0278-7407/91/917C-00866\$10.00

\section{INTRODUCTION}

The Phanerozoic buildup of Asia is still a matter of debate, and tracing the suture zones within the Asian continent is a major goal for many geologists. Concerning the Qinling belt of central China, some authors consider that the suture between North China (or Sino-Korean) and South China (or Yangtze) blocks is middle Paleozoic in age [Huang, 1978; Zhang et al., 1984; Mattauer et al., 1985, Xu et al., 1986] or late Paleozoic [Wang et al., 1982]; others claim its age to be early Mesozoic [Klimetz, 1983; Sengör, 1985; Hsü et al., 1987]. Whether the Qinling suture continues east of the Yellow Sea and crosses the Korean peninsula is an important clue for the knowledge of east Asia.

In spite of its limited size, the Korean peninsula is a patchwork of small crustal blocks divided by Phanerozoic mobile belts (Figure 1a). Until recently very little was known about the tectonic and geodynamic evolution of these belts.

The Nangrim-Pyeongnam block of North Korea is formed of Archaean to middle Proterozoic high-grade metamorphic rocks unconformably overlain by Sinian to Middle Ordovician deposits that represent the eastern extension of the North China platform [Kobayashi, 1953]. Its southern boundary with the Gyeonggi block is the Imjingang belt, formed of early Paleozoic metasediments unconformably covered by Carboniferous deposits [Lee, 1964].

In South Korea, the Ogcheon belt forms the boundary between the Archaean to middle Proterozoic Gyeonggi block to the northwest and the Ryeongnam block of the same age to the southeast [Figure 1b]. The Ogcheon belt was previously thought to be formed of late Proterozoic nonfossiliferous formations (the Ogcheon System, or Group of previous authors) [Nakamura, 1923] uncomformably overlain by an early Paleozoic platform sequence (the Joseon Supergroup), in turn discomformably covered by middle Carboniferous-Early Triassic coal bearing formations (the Pyeongan Group) [Inoue, 1907; Reedman and Um, 1975; Na, 1986; Kim, 1970; Kim et al., 1986].

It is widely accepted that Middle Jurassic tectonism (Daebo orogeny) is the most dominant orogeny related to the formation of Ogcheon belt. This view is supported by the widespread occurrence of "Jurassic" granites along the strike of the Ogcheon belt, and a model of Jurassic collision between two continental blocks (the Ryeongnam and Gyeonggi blocks) has been proposed for a long time [Kim, 1970]. A discussion on the role of the Jurassic tectonism is beyond the scope of this paper; nevertheless, it is worth noting that (1) on the basis of recent $\mathrm{Rb}$-Sr radiometric data, early Mesozoic granitoids were continuously emplaced from Middle or Upper Triassic to Upper Jurassic; (2) Triassic foliated granites crosscut the tectonic structures in the SW of Ogcheon belt; (3) the bulk of post-middle Permian sedimentary rocks in the Ogcheon belt have been deposited in a terrestrial environment; (4) evidence for a Mesozoic suture in the Ogcheon belt is completely lacking; (5) Permian to Mesozoic accretionary wedge(s) and/or collision belts are located farther to the east within the Japanese archipelago; and (6) angular unconformities have been generally overlooked.

Therefore it appears that the effects of the so-called Daebo orogeny have been greatly overestimated in the past, and a model of polycyclic evolution involving pre-Jurassic tectonic phases is more likely. In addition, recent sedimentological [Chough, 1981], micropaleontological [Lee et al., 1972; Kim, 1986; Lee J.H., 1987; Lee J.H. et al., 1989], geochemical [Cluzel et al., 1989], and structural data (this study) reveal that the Ogcheon Group is actually a stack of nappes with contrasting lithologies [the Ogcheon Supergroup] bom of the closure of an early Palcozoic rift [Cluzel, 1987; Cluzel and Cadet, 1989; Cluzel et al., 1990]. 


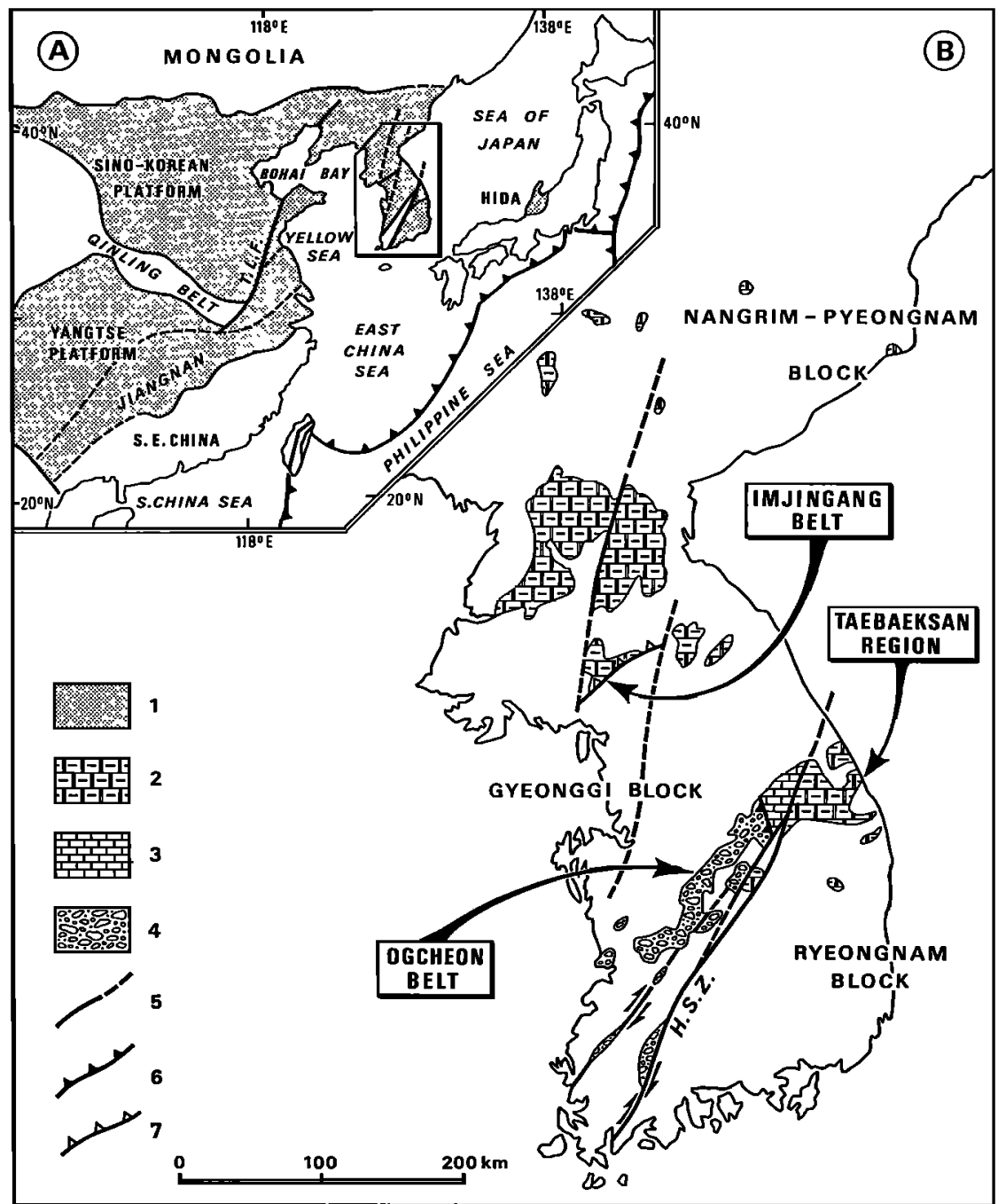

Fig. 1. (a) General sketch map of east Asia showing the present day position of the Pacific active margin and setting of the main cratonic blocks (pattern 1)(adapted from Yang et al. [1986], and Ernst et al. [1988], T.L.F. is the Tanlu fault. (b) Structural sketch map of the Korean peninsula (modified from 1: 2,000,000 Geological map of Korea [Chun and Um ,1984] (only arly Paleozoic formations represented), 2, Joseon Supergroup with North China Cambrian biofacies; 3, Jiangnan biofacies; 4, Ogcheon Supergroup; 5, Mesozoic wrench faults; 6, Jecheon-Tan'yang thrust (Joseon-Ogcheon Sgr. boundary); 7 , Imjingang belt; H.S.Z. is the Honam Shear Zone.

Based upon previous mapping by Korean geologists, detailed field surveys have been conducted in the Ogcheon belt by one of us (D.C.) from 1985 to 1990 . Field and microstructural analysis provide evidence for a post-middle Silurian-premiddle Carboniferous ductile stacking which resulted in the consolidation of the Korean peninsula.

\section{THE STRATIGRAPHY OF THE EARLY PALEOZOIC UNITS}

In the Ogcheon belt, we have divided the early Paleozoic Ogcheon Supergroup into five main tectonic units, the Iwharyeong, Poeun, Turungsan, Chung Ju and Pibanryeong nappes which are stacked in that order from bottom to top (Figure 2) [Cluzel and Cadet, 1989; Cluzel et al., 1990]. These lithotectonic units are born of the different paleogeographic zones of an early Paleozoic rift basin. The nappes that constitute the Ogcheon Supergroup are thrust on to the Yeongweol unit of the weakly metamorphosed Joseon Supergroup (Figure 2). This latter unit [the Yeongweol-type sequence] is composed of Middle Cambrian to Middle Ordovician [Kobayashi, 1953; Reedman and Um, 1975], $2000 \mathrm{~m}$ thick, quartzite, shale and limestone series which represent an outer shelf at the relatively stable southeast margin of the rift (Figure 3).

The Yeongweol unit which may be correlated with the Cambrian Jiangnan bioprovince of the Yangtse (South China) platform [Kobayashi, 1953, 1966] (Figure 1a), is subsequently thrust to the east on to the Carboniferous-Permian "molasse" that rests unconformably on the Cambrian-early Middle Silurian [Lee H.Y., 1980] Jeongseon unit of the Joseon Supergroup (Figure 2), as a result of Indosinian tectonism and thus appears as parautochthonous. The Jeongseon unit (Jeongseon-type sequence) that yields Silurian conodonts may 


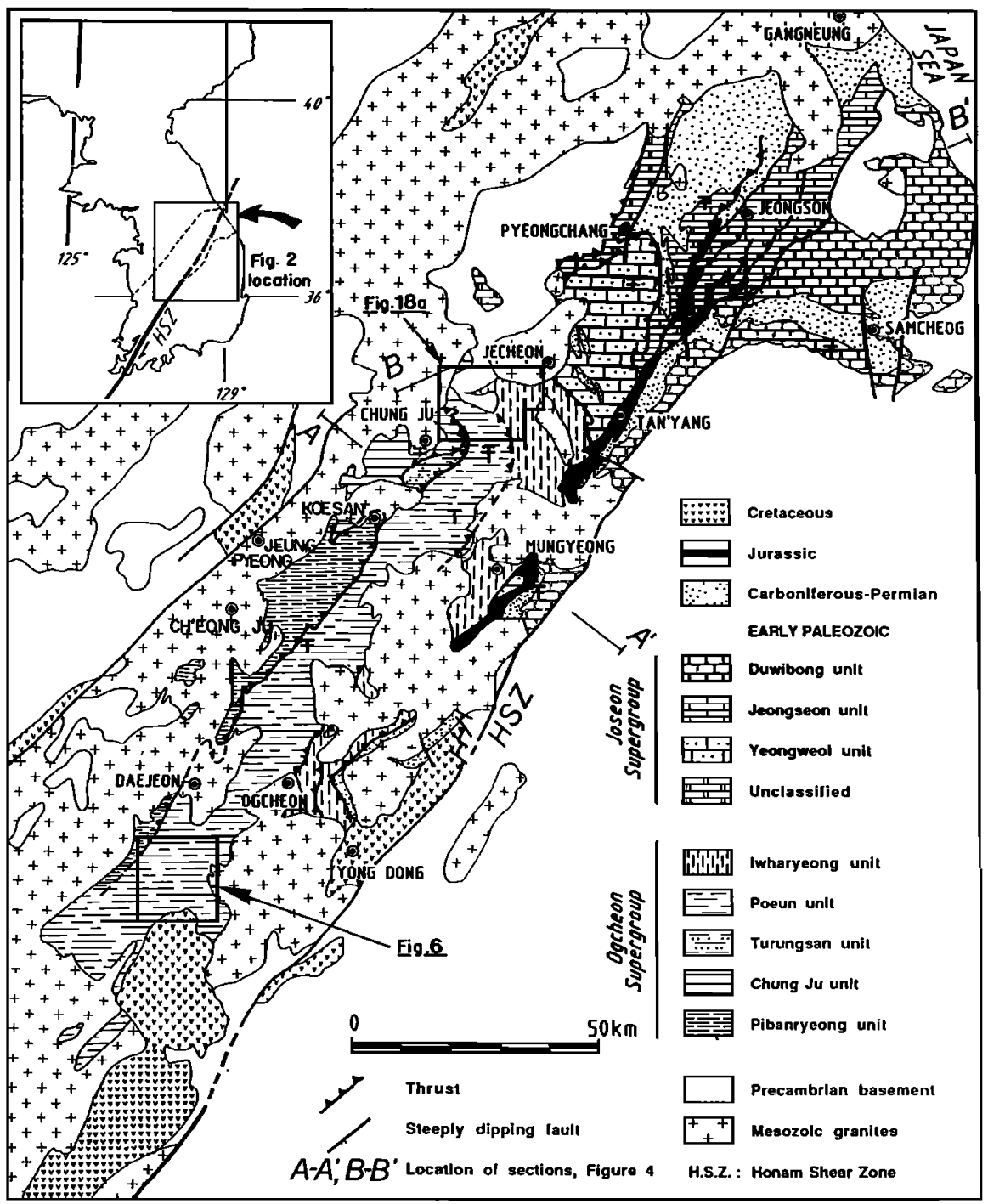

Fig. 2. Geological sketch map of the Ogcheon belt (modified from a compilation of existing 1:50,000 geologic maps, Korea Institute of Energy and Resources Editor, Seoul). Lithotectonic units are defined according to Reedman and Um [1975] (Joseon Supergroup), Cluzel and Cadet [1989] and Cluzel et al. [1990] (Ogcheon Supergroup). Thrusts of different ages are not differentiated. It is noteworthy that the Honam Shear Zone is not a single fault, especially in the NE of the belt, where it becomes a relay zone which was reactivated several times (profiles $A-A^{\prime}$ and B-B' are shown in Figure 4).

also be correlated with the South China platform and therefore represents a lateral equivalent of the Yeongweol unit.

The Ryeongnam block and its Cambrian to Middle Ordovician cover (Duwibong-type sequence) is located to the southeast of the Late Triassic Mungyeong-Tan'yang-Jeongseon coalfield emplaced along a major dextral fault, the Honam shear zone [Yanai et al., 1985; Cluzel, 1990]. The Duwibong sequence has been correlated with the North Korea-North China Cambrian bioprovince [Kobayashi, 1953, 1966] and therefore has no direct relationship with the units located to the northwest of the fault. This block was originally connected to the Pyeongnam block of North Korea and brought to its present position as a result of major pre-Jurassic dextral motion [Cluzel et al., 1991a].

The Iwharyeong, Poeun, and Turung San units display a characteristic association with (1) a basal prerift platform sequence composed of limestone, quartzite, and mudstone or carbonaceous mudstone and (2) a syn-rift sequence characterized by volcanics and diamiclites. The three previously mentioned tectonic units represent a transitional domain located between the outer shelf (the Yeongweol sequence) and the deep basin area (the Chung Ju and Pibanryeong units) (Figures 3 and 4). This transitional domain displays the characteristics of a wide extensional margin where synsedimentary faulting occurs. The diamictites originated as submarine debris flows [Chough, 1981] that reworked alluvial fan deposits derived from the Precambrian basement and its Cambrian to Early Ordovician cover [Lee J.H., 1987; Lee J.H. et al., 1989].

The Chung Ju and Pibaryeong units (the deeper part of the basin) (Figures 3 and 4), are composed of a thin basal quartzite associated with Cambrian limestone or dolomite [Lee et al., 1972]. This platform sequence is overlain by volcanics or vol- 


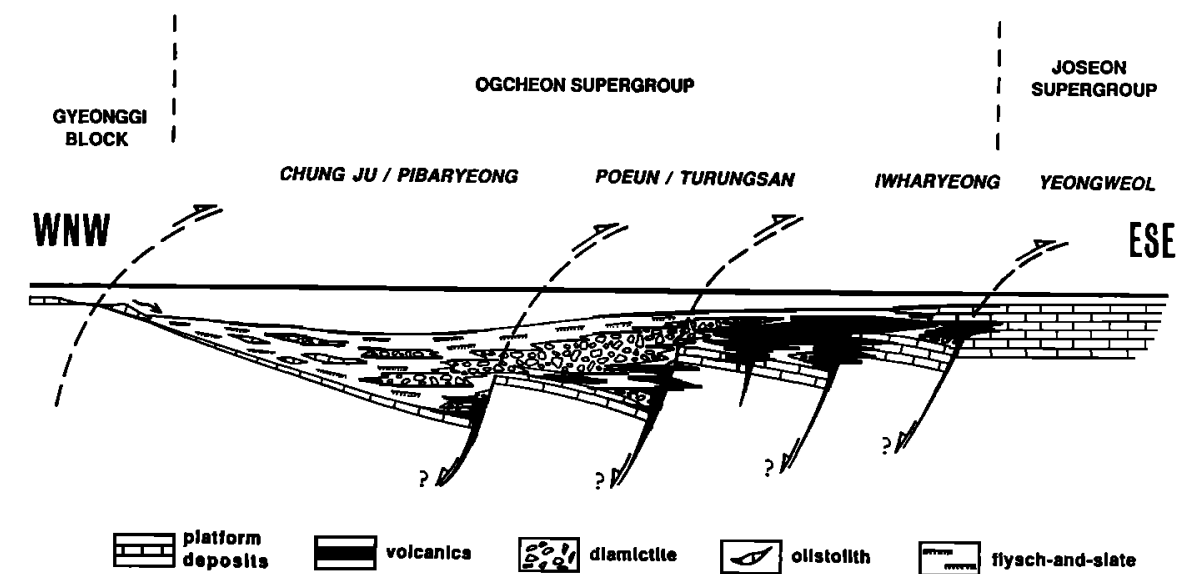

Fig. 3. Idealized palinspastic reconstruction of the early Paleozoic Ogcheon rift basin, showing the relationship of the main lithotectonic units and inferred synsedimentary normal faults that have been possibly reactivated as thrusts.

NW
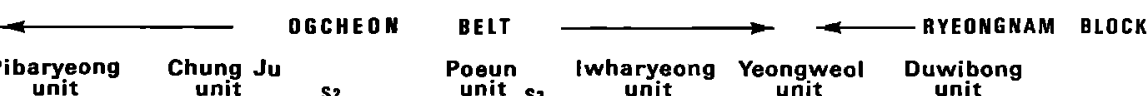

SE

A

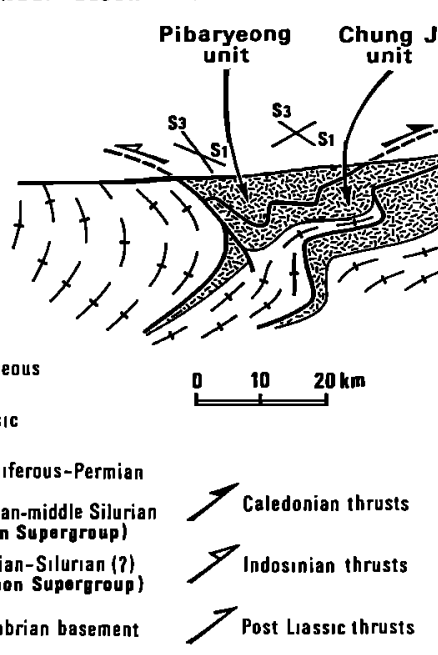

S2 Poeun Iwharyeong Yeongweol Duwibong
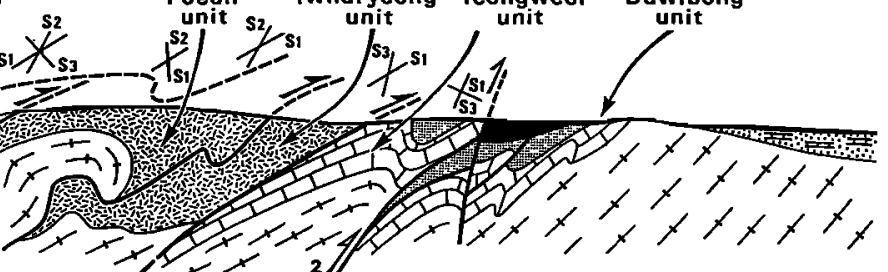

$A^{\prime}$

E

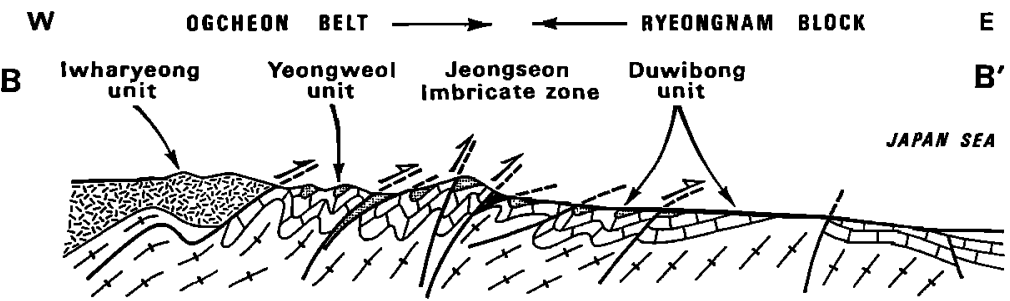

Fig. 4. Simplified sections across the Ogcheon belt assuming a pre-Carboniferous major phase of ductile thrusting associated with isoclinal folding (adapted from Cluzel et al. [1990]). Mesozoic granites have been omitted. Location of profiles is indicated on Figure 2.

canogenic sedimentary rocks and by distal turbidites (flyschlike deposits) which locally contain thin interbedded diamictites. Kilometer scale limestone olistoliths, probably derived from the prerift basal sequence, are located at the lower third of the flyschlike sequence. (For a more accurate account of the stratigraphy of Ogcheon Supergroup, see Cluzel et al. [1990]).

Most proposed geodynamic models integrate the Korean peninsula into a scheme of oceanic active margin since the Paleozoic, while the amphibolite complex of the Ogcheon belt has been generally interpreted as an ophiolite sequence representing an oceanic suture [Kim, 1975; Kim and Kim, 1976; Lee D.S., 1980; Lee et al., 1980; Miyashiro, 1981; Lee et al, $1982 ; \mathrm{Na}, 1990]$. However, this interpretation does not fit the geochemical features of Ogcheon metavolcanics. The metavolcanic complex displays a bimodal association of metabasalts or metadolerites associated with metatrachytes and rare metarhyolites. Most of basic volcanics have been emplaced as hyp- abyssal complexes (sills, dikes, and laccoliths) that crosscut the basal platform sequence of the Ogcheon Supergroup, while acidic volcanics are mainly represented by ash flows or volcaniclastic rocks; nevertheless, stratabound basic volcanic and volcaniclastic rocks are also present.

The scarcity of rocks of intermediate composition, occurrence of Fe and Ti-rich basic facies, high level of incompatible elements $(1.5<\mathrm{TiO} 2<4.5 \mathrm{wt} \% ; \mathrm{Zr}>100 \mathrm{ppm})$, high light rare earth elements contents $(3<(\mathrm{La} / \mathrm{Yb}) \mathrm{N}<13)$ and "immobile" elements ratios (Ti/V $=0.50$ on average, $\mathrm{Y} / \mathrm{Nb}>$ 1), are features of tholeiitic transitional suites, commonly emplaced in intracontinental settings [Cluzel et al., 1989; D. Cluzel, Ordovician bimodal magmatism in the Ogcheon belt (South Korea)-Intracontinental volcanic activity related to early Palcozoic synsedimentary tectonics, submitted to Joumal of Southeast Asian Earth Sciences, 1991; hereafter referred to as 
Cluzel, submitted manuscript, 1991]. The low $E N d$ ratio of basic rocks and negative values of trachyte and rhyolite suggest that a crustal contamination occurred during the magma genesis of Ogcheon metavolcanics [Cluzel, submitted manuscript, 1991]. Thus, taking into account both the overall characteristics of the sedimentary environment and the petrological and geochemical features, these volcanics were likely to have erupted in an intracontinental rift; therefore they cannot represent oceanic remnants as has been previously assumed.

After a Middle Silurian (?) to middle Carboniferous sedimentary hiatus, paralic platform deposits (the Pyeongan Group) unconformably overlie the Joseon Supergroup in the moderately subsiding foreland of the Ogcheon belt.

\section{THE SUPERPOSED DEFORMATIONS IN THE OGCHEON SUPERGROUP}

In contrast with the slightly folded or unfolded platform domain, the internal domain of the Ogcheon belt is composed of medium-grade highly deformed rift metasediments which constitute the Ogcheon Supergroup. These metamorphic units are affected by polyphase tectonism corresponding to four main tectonic events D1 and D2 (pre-Carboniferous), D3 (Middle Triassic), and D4 (post-Liassic).

The age and relative timing of the different deformation phases have been deciphered from field obervation of crosscutting foliations, refolding pattems, etc, along more than fourty detailed sections across the belt, microstructural analysis of several hundred rock thin sections, and a comparison of the structural features of the four main stratigraphical units (Ogcheon, Joseon, Pyeongan and Daedong groups or supergroups).

The superimposed deformations indicate that the regional structures are obviously related to D2, D3, and D4, whereas the earlier D1 structures are often transposed. Similar geometric characteristics show that $\mathrm{D} 1$ and $\mathrm{D} 2$ belong to a single progressive deformation.

The most suitable data are provided by the schistose diamictites where stretched pebbles unambiguously record the earliest deformations. The quartzite/schist intercalations at the base of the sequence are also good tectonic markers especially for medium scale folding. In contrast, the early structures in most of metapelitic terranes (schists, mica schists and low-grade gneisses) are transposed and become hardly decipherable.
On the contrary, the thick metadoleritic or metagabbroic amphibolites are often devoid of any tectonic foliation; in addition, they have provided Triassic ${ }^{39} \mathrm{Ar} / 40 \mathrm{Ar}$ ages [Lee, 1988]. Consequently, they have sometimes been misinterpretated as early Mesozoic post-tectonic intrusives; actually, the dated amphiboles are metamorphic hornblendes that may be related to the Middle Triassic tectonometamorphic event. A careful examination reveals that the amphibolite bodies are located approximately at the same stratigraphic level throughout the belt; in addition, they display foliated margins and boudin structures at a larger scale and therefore appear as pretectonic.

\subsection{D1-2 First Stage Continuum}

3.1.1. D1 structures. The first observable deformation is characterized by the regional S1 foliation, L1 stretching lineation and F1 isoclinal folding. The D1 structures are well documented in the Iwharyeong and Poeun units that are located in the medium part of the nappe pile (Figure 2). The S1 foliation and the associated stretching lineation appear to be closely related to the ductile thrusts that limit the main tectonic units of the Ogcheon Supergroup. The intensity of the D1 deformation significantly increases in the vicinity of the main thrusts and also from the SE to the NW, i.e., from the bottom to the medium part of the nappe pile. This feature has been already noticed by some authors (see, for example, Lee and Kim [1988]). It was interpreted as a result of strain attenuation in the hinge of a large-scale recumbent fold; such an interpretation is not consistent with F1 hinge location and bulk geometry of sharp F1 folds; it is better accounted for by the strain attenuation toward the front of a large thrust sheet. In the parautochthonous Yeongweol sequence, the early deformations are weak and severely overprinted by D3 (Indosinian) tectonism [Cluzel, 1989b]. An unconformity between Ordovician limestones and middle Carboniferous deposits (Gabsan formation) has been noticed for a long time by mapping geologists between Jecheon and Yeongweol [Geological Society of Korea, 1966] but this evidence has been generally overlooked. In the uppermost units [the Chung Ju and Pibarycong nappes] which correspond to the hanging wall of the stack, the strain ratio decreases upward.

$\mathrm{S} 1$ is commonly parallel to the bedding and corresponds to the axial plane foliation of the F1 isoclinal recumbent folds.

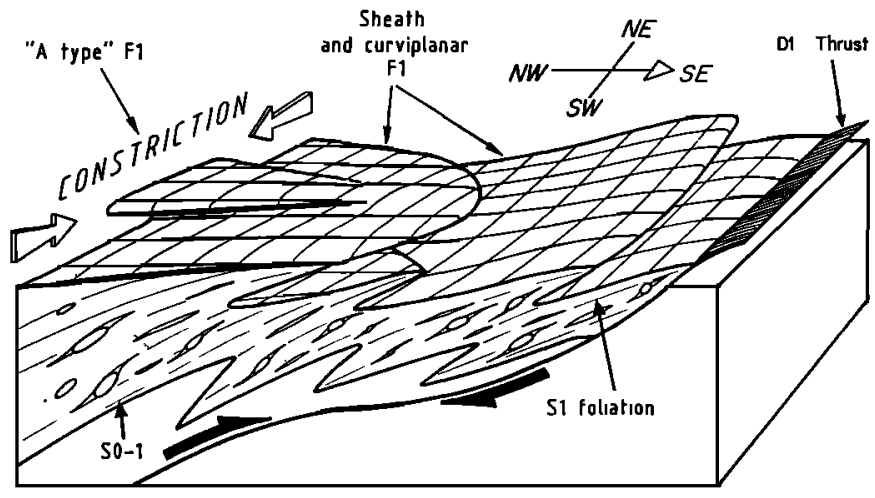

Fig. 5. Idealized block diagram of the progressive D1 deformation, showing the association of thrusts with isoclinal, curviplanar or sheath folds, "A type" folds and penetrative S1 foliation during one tectonic event. At high strain rates, all F1 axes tend to be parallel to the stretching lineation which indicates the direction of overthrusting. Because of the lack of preexisting surface, no F1 is observed in the medial part of thick debris flow units. 


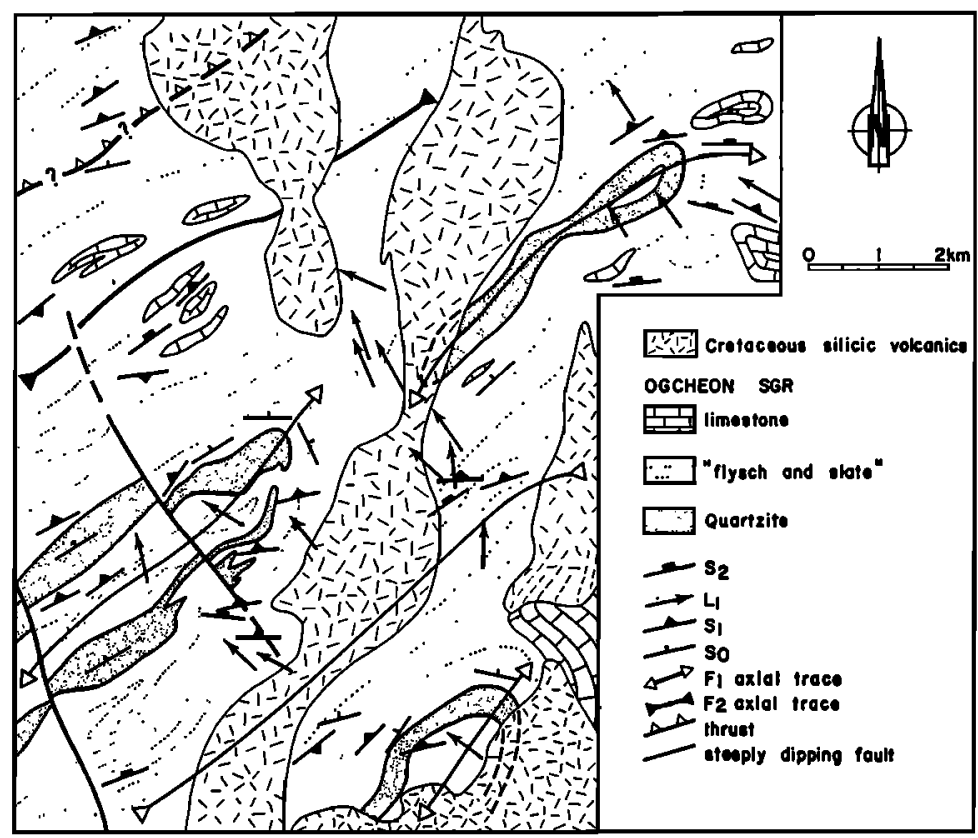

Fig. 6. Geologic map of the Geumsan area (modified from the 1: 50,000 geological map of Korea, Geumsan sheet [Hong and Choi, 1978]. F1 folds with axes close to L1 ("A type" ?) are refolded by subsequent (F3 ?) synform with NE-SW direction (for location, see Figure 2).

Except in the quartzites, $\mathrm{S} 1$ always transposes $\mathrm{S} 0$ and is noted S0-1. It is important to note that in unbedded debris flow deposits, S1 occurs as the earliest surface; thus no mesoscopic F1 fold can be observed in the inner part of the thick diamictite bodies (Figure 5). In highly deformed domains, most of F1 isoclinal folds are sheath folds [Nicolas and Boudier, 1975; Cobbold and Quinquis, 1980; Henderson, 1981] and "A type" (or constrictional) folds (basically formed by $\mathrm{Y}$-parallel shortening). Both fold types have axes parallel to the stretching lineation. In less deformed areas, the F1 axes display a variable attitude in regard to the stretching lineation, and curviplanar folds are locally observed (Figure 5).

Due to the subsequent refolding and transposition, regional F1 folds are rarely observed. Nevertheless, kilometer scale "A type" and/or sheath folds are located in the Geumsan area, 15 km SSW of Taejeon (Figure 6) [Hong and Choi, 1978], and both are refolded by $F 2$ recumbent to the SE or subsequent folds (Figure 7). Moreover, mesoscopic "A type" folds are widespread throughout the Poeun unit. "Closed" interference patterns are often observed on outcrops, but actual sheath folds are not so frequent. Nevertheless, some beautiful examples are exposed in metamorphosed limestones at the eastern entry of the Chubu tunnel (near Geumsan, $10 \mathrm{~km}$ south of Taejeon) and near Worak San (24 km SE of Chung Ju).

$\mathrm{S1}$ is a syn-metamorphic feature evidenced by syntectonic mineral growth. Rotated synkinematic garnets, oriented mica flakes, and amphibole needles in pressure shadows are diagnostic of syntectonic metamorphism. The mineral paragenesis contemporaneous with $\mathrm{S1}$ ranges from the greenschist facies to the lower amphibolite facies of the medium pressure type metamorphism. The metapelitic rocks display characteristic mineral associations such as staurolite, phengite, biotite, almandine, chloritoid, and metastable relics of kyanite. In metabasites, the mineralogy is often complex due to superimposed metamorphic events and incomplete retrograde metamorphic transformations. Higher- grade rocks contain relics of metamorphic brownish homblende lately replaced by green

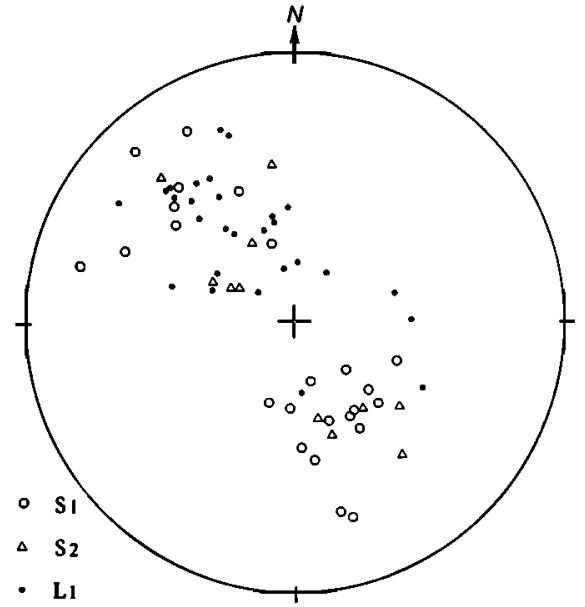

Fig. 7. Stereoplot of structural elements related to Figure 6; note the scattering of S1 and S2 poles as an effect of F3 (F4 ?) folding. In spite of refolding, except for dip variations, the original trend of $\mathrm{L} 1$ remains more or less unchanged.

homblende or tremolite, plagioclase (An40-20), epidote, sphene, and rare biotite. Such associations are diagnostic of the epidote-amphibolite facies of medium-pressure metamorphism or amphibolite facies of low-pressure.

S1 bears a widespread composite mineral and/or stretching lineation (L1). The strike of $\mathrm{L} 1$ restored in its pre-D3 position is $\mathrm{N} 140^{\circ}-160^{\circ} \mathrm{E}$ on average (Figure 13 ). The mineral lineation is marked by hornblende needles in basic schists and by synkinematic calcite, quartz, phengite, biotite, and chlorite pressure shadows around strain resistant minerals such as pyrite, magnetite, epidote, or garnet. The stretching along the 
lineation is marked by the deformation of passive markers such as plastically stretched pebbles in diamictites or synkinematic crystal growth in pressure shadows. It is worth to note that in low-grade zones, monocrystalline quartz grains and quartzite pebbles are relatively resistant and develop spectacular pressure shadows composed of synkinematic biotite, quartz, and calcite. In higher-grade zones, quartz grains become plastically deformed and siliceous pebbles may be severely stretched. The limestone and above all, shale clasts which have approximately the same rheological properties as the matrix, provide excellent strain markers. For example, the maximum finite extension ratio of some elongated limestone pebbles may reach $400 \%$ and more.

The deformation regime of the D1 tectonic phase has been investigated in sections perpendicular to the foliation and parallel to the stretching lineation. Noncoaxial strain features indicating a NW over SE sense of shearing are commonly observed at the scale of the outcrop and in oriented thin sections. The rotational criteria are sigmoidal or "snowball" synkinematic garnets [Schoneveld , 1977], asymmetric pressure shadows, shear bands, sigmoidal mica flakes, en-echelon boudinaged crystals, asymmetric shape fabrics, and $\mathrm{S}-\mathrm{C}$ fabrics in mylonites [Berthé et al., 1979; Simpson and Schmid, 1983; Cobbold et al., 1987] (Figure 8). Thus, the D1 deformation clearly appears to be related to the ductile stacking up of the nappes towards the SE.

3.1.2. D2 structures. The F2 folds are responsible of the average NE-SW trend of the central Ogcheon belt (Figure 2) where the early thrusts and S1 have been folded together. In contrast with F1 isoclinal folds, F2 folds are open to tight and moderately recumbent to the SE (Figure 4) with subhorizontal axes (if not refolded by F3 folds). The $\$ 2$ regional foliation is the most prominent regional feature and was often misinterpreted as S1. In the hinge zones or in the NW normal limbs of the F2 folds, S2 is commonly a NW dipping strain slip cleavage that clearly cuts across the $S 1$, whereas in the overturned southeastern limbs, S2 often transposes S1 or S0-1 (Figure 9). Locally (i.e., to the south and to the NE of Chung $\mathrm{Ju}$ ] (Figure 2) S0-1 is transposed by S2 at a regional scale. In such areas, the regional $S$ surface is a composite foliation noted S0-1-2. In the schistose diamictites, the stretched limestone and shale clasts are crenulated and microfolded (Figure 10) whereas the quartzite pebbles display complex shapes due to the superimposed deformations (Figure 11).

On the S1-2 transposed foliation, the stretching axis related to the composite L1-2 stretching lineation remains in the same orientation. In particular, asymmetric quartz pressure shadows developed around D1-related biotite porphyroblasts have the same NW-SE strike as the stretched pebbles in the diamictites and also indicate SE directed shear (Figures 8i and 8j). Therefore it may be inferred that D2 is not related to a distinct tectonic event and that D1 and D2 deformations are in a continuum (D1-2). S1 and related isoclinal F1 folds were generated by a shearing deformation process during the ductile nappe emplacement and formed an acute angle with respect to the general attitude of bedding $(\mathrm{S} 0)$; owing to intense flattening and stretching, $S 1$ progressively transposed S0 and became almost parallel to the shearing plane. Therefore, a new foliation (S2) that formed an appropriate angle with respect to the shearing plane (Figure 12) was generated together with F2 folds during a continuous progressive deformation. Nevertheless, it appears that the shear strain related to D2 is far less intense than that of $\mathrm{D} 1$. The $\mathrm{D} 2$ deformation regime corresponds to a moderate subhorizontal shearing combined with a predominant flattening (oblate strain).

The intensity of the D2 as well as the D1 deformations increases from the NE to the $\mathrm{SW}$, along the strike of the belt, and from the bottom to the top of the nappe pile. The S2 folia- tion is almost lacking in the Iwharyeong nappe north of Mungyeong which is a S0-1 monocline. On the contrary, it is well expressed in the central part of the Poeun unit, especially between Poeun and Miweon (Figures 13 and 14). In the uppermost Pibanryeong nappe, the S2 foliation with a NE-SW strike is apparently lacking; nevertheless, a careful examination of the basal part reveals that $\mathbf{S 1}$ in this unit has the same attitude and was generated during the same time as S2 in the underlying units that are located in medium part of the nappe pile (Chung Ju and Poeun units). Consequently, the nappes appear to have been piled up sequentially from the bottom to the top of the stack, i.e. from SE to NW. The emplacement of the uppermost units was likely contemporaneous with the folding of the early thrusts in the medial part of the belt. Besides, the lowermost Iwharyeong and Yeongweol units that underwent a lesser amount of shearing deformation remain almost undisturbed by $\mathrm{F} 2$ folding (Figure 15).

\subsection{D3 and D4 Tectonic Overprint}

At a regional scale, $\mathrm{S} 1$ or $\mathrm{S} 1-2$ and occasionally $\mathrm{F} 1$ or $\mathrm{F} 2$ are folded by F3 and F4 folds which also result in the scattering of the L1 (or L1-2) stretching lineation (Figures 13 and 16). The $\mathrm{F} 3$ folds originally strike $\mathrm{N} 20^{\circ} \mathrm{E}$ on average, and they are responsible for the NNE-SSW regional trend of the NE part of the Ogcheon belt [Barrier et al., 1989; Cluzel, 1989b]. In the central Ogcheon belt, the axial plane foliation of the F3 folds is commonly a strain slip cleavage (S3) dipping $70^{\circ}$ to the ESE on average that cuts across S1, S2 or S1-2. As an effect of the F3 flexural folding, the strike of the $\mathrm{L} 1$ lineation is changed from NW-SE to NNE-SSW in the western overturned limbs of the F3 folds (Figure 13).

The D3 microstructures usually indicate WNW vergence. Locally (near Koesan, $30 \mathrm{~km}$ SW of Chung Ju), the L1-2 stretching lineation has been rubbed out and L3 stretching lineation develops with a ESE-WNW strike. L3 is mainly composed of quartz-chlorite pressure shadows developed around inherited D1 gamet porphyroblasts. On thin sections perpendicular to $S 3$ and parallel to L3, asymmetric pressure shadows indicate an incipient shearing with an east over west sense of movement, whereas unarranged inclusions of the garnet porphyroblasts indicate that garnet is not synkinematic with S3 (Figure 17a and 17b). In contrast, when observed in sections perpendicular to the composite S1-3 foliation and parallel to the direction of the inferred L1 lineation (that is NW-SE), helicitic inclusions reveal a NW over SE rotation (Figure 17c) obviously corresponding to D1 or D1-2.

Locally, synkinematic to postkinematic andalusite porphyroblasts (Figure 17d) and minor sillimanite associated with S3 postdate S1-2 and reveal that D3 was developed in low pressure metamorphic conditions. Therefore it is almost everywhere possible to distinguish S3 from S2 or S1-2.

In low-dip areas, especially in northwestern normal limbs of the F1-F2 folds and in the absence of F3 folds, D4 resulted in broad, south facing, F4 gentle folds; in such cases, the strike of $\mathrm{Ll}$ remains in the same orientation. In contrast, in areas affected by $\mathrm{F} 3$ folding, the average pre-D4 bedding/[oliation attilude originally strikes NNE-SSW and steeply dips to the WNW or to the ESE; therefore D4 resulted in the bending of the steeply dipping regional bedding/foliation into broad $\mathrm{F} 4$ folds with subvertical axes.

An example of a large scale interference structure due to the superimposition of D1-2, D3, and D4 events, is well exposed in the Busan gneiss dome area (east of Chung $\mathrm{Ju}, \mathrm{SW}$ of Jecheon] (Figure 18). In this area, three nappes related to the D1-2 tectonism are superposed: the Iwharyeong, Poeun, and Chung Ju units from bottom to top. The Iwharyeong unit is backthrust to the west onto the Poeun unit along a N-S trending high-angle reverse fault. The $S 1$ and S1-2 foliations 

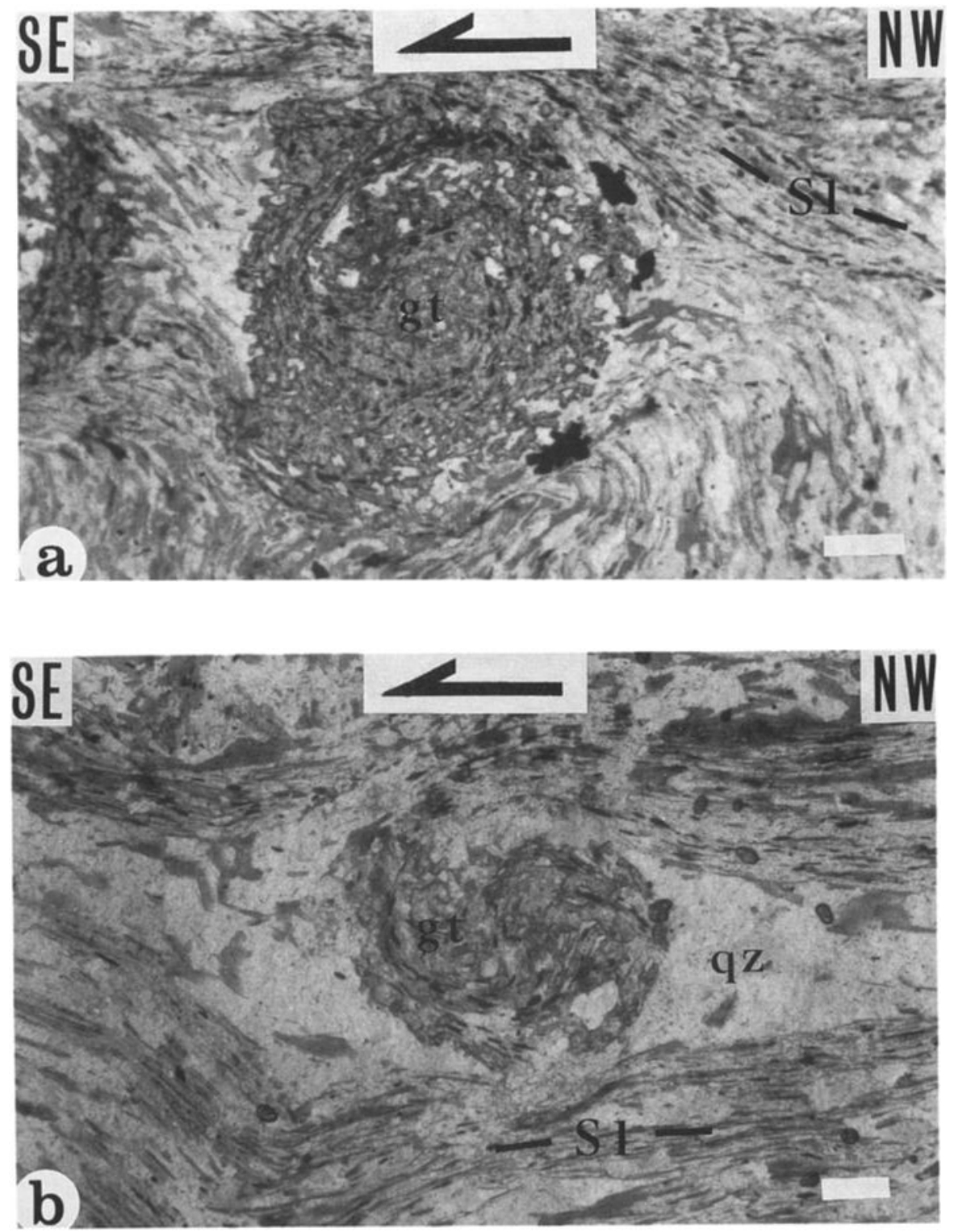

Fig. 8. Microstructures (shear criteria) related to the D1-2 southeast directed overthrusting. (a) "Snowball" synkinematic gamet displaying anticlockwise rotation (S1-2 foliation, Poeun unit; close to the contact with the Chung Ju unit, Chung Ju dam) (scale bar: $1 \mathrm{~mm}$ ). (b) "Snowball" synkinematic garnet displaying anticlockwise rotation (S1 foliation, Poeun unit, south of Chung Ju City) (scale bar: 1 $\mathrm{mm}$ ). (c) Helicitic synkinematic garnet with $120^{\circ}$ anticlockwise rotation. (S1 foliation, basal part of the Pibanryeong unit, SW of Koesan) (scale bar: $1 \mathrm{~mm}$ ). (d) Asymmetric pressure shadows around strainresistant epidote grains (L1 lineation in epidote-tremolite/actinolite schist, volcanic complex, Poeun unit, $18 \mathrm{~km}$ SW of Jecheon) (scale bar: $5 \mathrm{~mm}$ ). (e) Asymmetric quartz pressure shadows around magnetite grains, note that magnetite crystals are slightly stretched (Li lineation in magnetite-muscovite schist, Poeun unit, $6 \mathrm{~km}$ NNW of Poeun)(scale bar: $5 \mathrm{~mm}$ ). (f) Asymmetric pressure shadows around stretched quartz and quartzite clasts in a schistosed diamictite. The pressure shadows are made of calcite, quartz and biotite (debris flow deposit, Poeun unit, $9.5 \mathrm{~km}$ NE of Ogcheon) (scale bar: $5 \mathrm{~mm}$ ). (g) Asymmetric shape fabrics and pressure shadows around stretched pebbles in a low grade schistose diamictite (Iwharyeong unit, $15 \mathrm{~km}$ south of Jecheon ) (scale bar: $5 \mathrm{~mm}$ ). (h) Asymmetric pressure shadows and shape fabrics in a fine grained schistose diamictite (Poeun unit, $12.5 \mathrm{~km}$ NE of Ogcheon) (scale bar: $1 \mathrm{~mm}$ ). (i) Asymmetric shape fabrics in a poorly sheared diamictite. Thin layers of debris flow deposits interbedded in the limestones at the top of the pre-rift sequence (Iwharyeong unit, $10 \mathrm{~km}$ south of Jecheon) (scale bar: $5 \mathrm{~mm}$ ). (j) L1-2 composite stretching lineation : asymmetric pull apart structure and associated quartz pressure shadows on D1-related biotite flakes (middle part of Poeun unit, $14 \mathbf{~ k m}$ NNE of Ogcheon) (scale bar: $1 \mathrm{~mm}$ ). 
1138
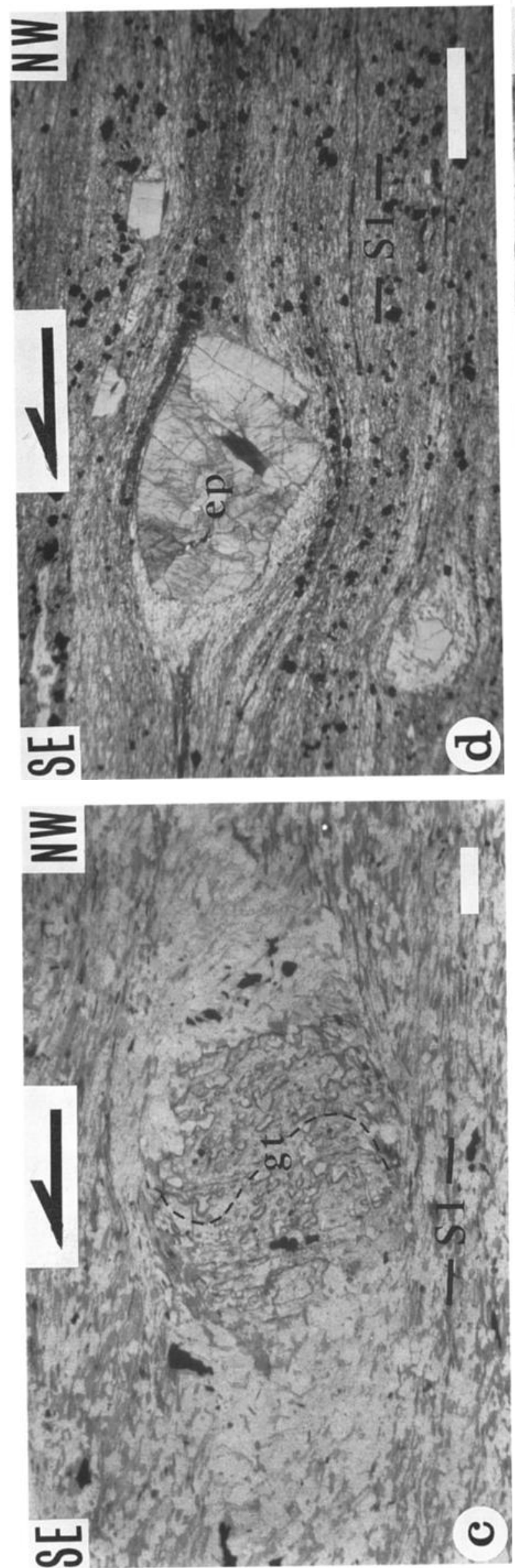

Cluzel et al.: Ogcheon Belt, South Korea
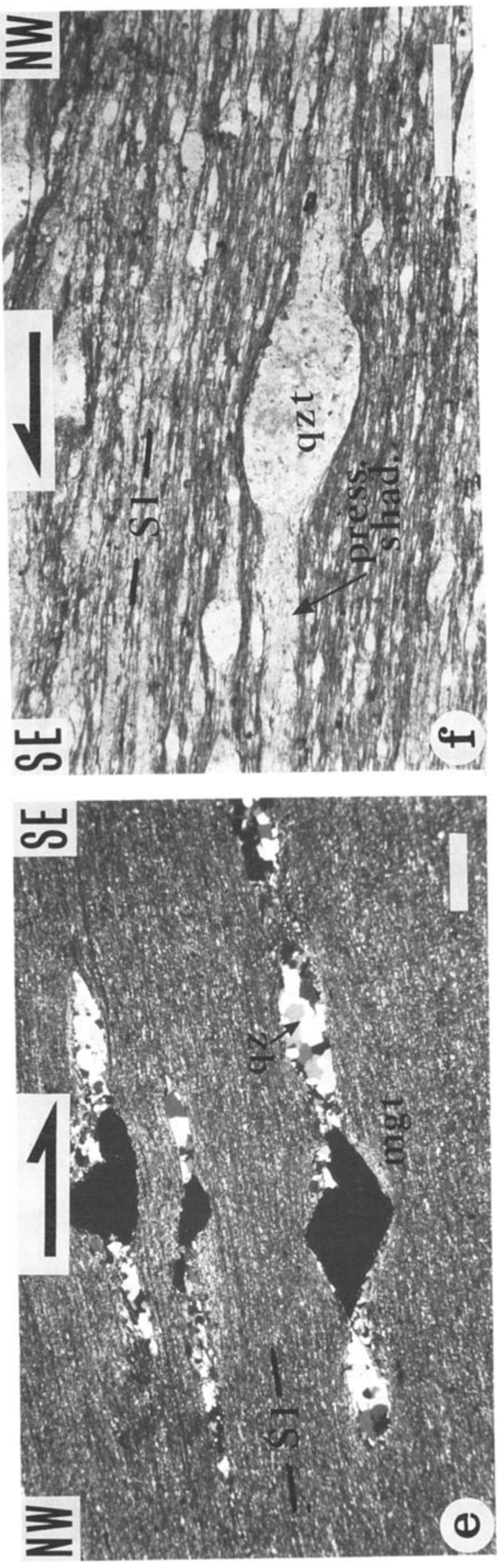

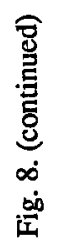



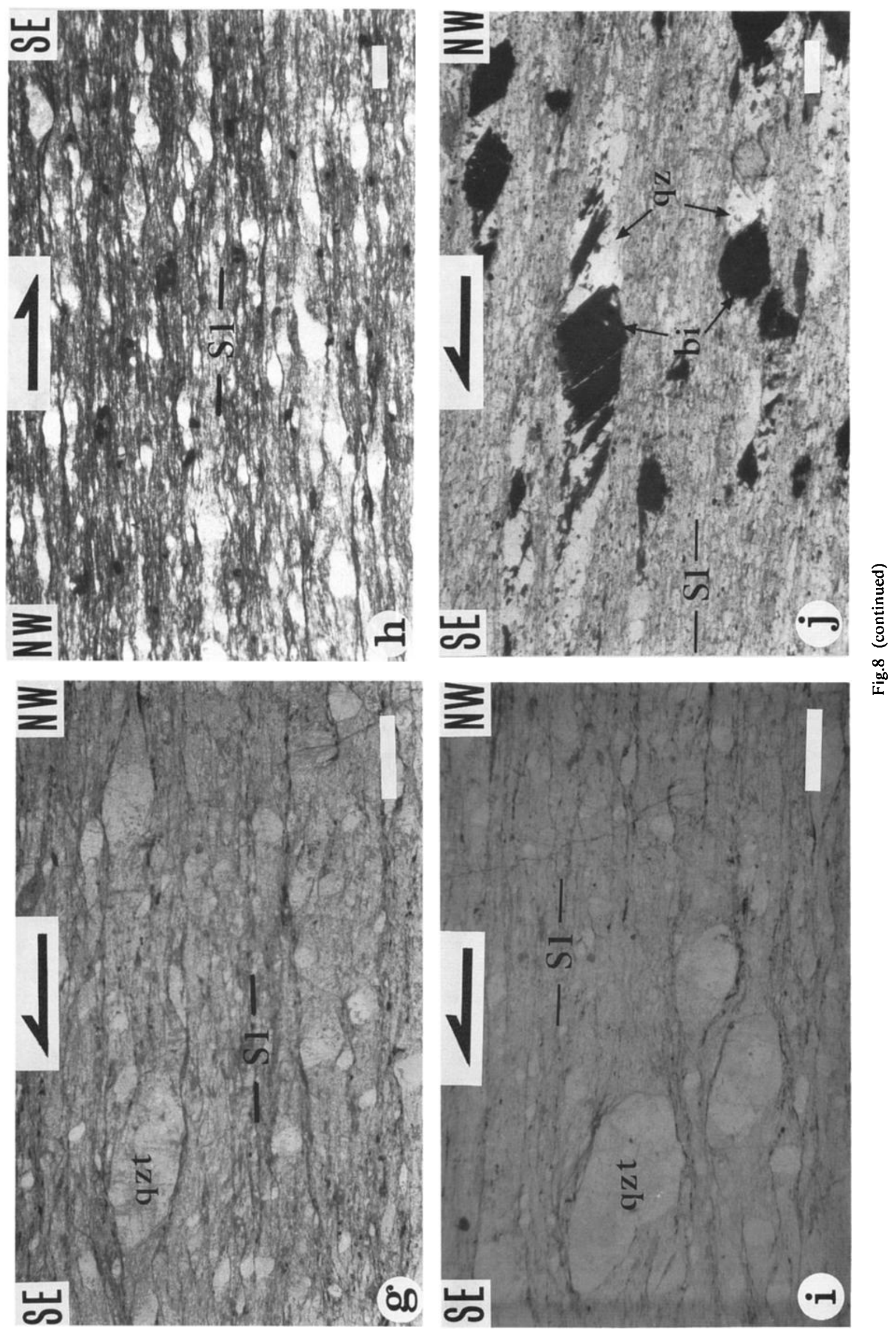

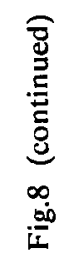




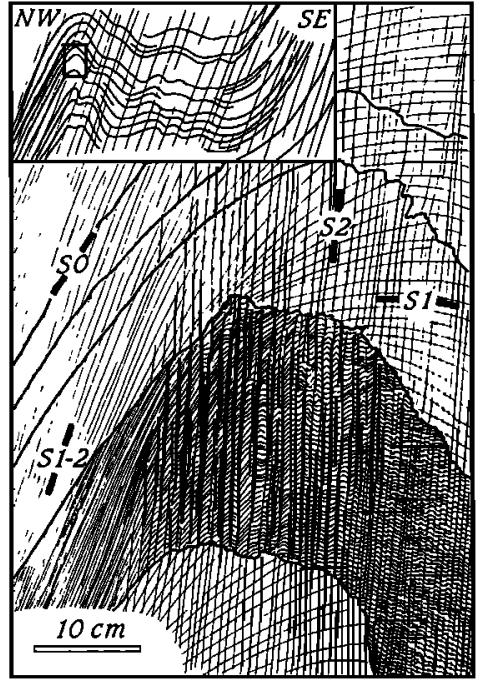

Fig. 9. Profile of southeast facing F2 fold in black shales (7 $\mathrm{km}$ north of Poeun), note that S2 transposes $\mathrm{S} 1$ in the $\mathrm{NW}$ dipping normal limbs, forming a composite S1-2 foliation, whereas $\mathbf{S} 2$ cuts across $S 1$ in the hinge zones. It is noteworthy that in Poeun area, many quarries work out slates in F2 limbs where S0, S1, and S2 are parallel.

are folded by F3 and subsequently refolded by F4 folds. The main structures in this area are the Chung Ju brachysynform, where the Chung Ju unit is preserved, and the Busan dome. The latter structure is a basement culmination issued from interference between F3 and F4 anticlines; it is mainly composed of porphyroblastic augen gneisses and S-C mylonites. The mylonites and augen gneisses display prominent stretching lineation and, locally, sheath folds. Shear criteria indicate pre-D3 SE or SSE directed shearing (Figures $19 \mathrm{~d}$ and $19 \mathrm{e}$ ). The stretching lineation in the metasedimentary cover of the dome and the F1 axes are parallel to the lineation within the dome itself; both are obviously related to the D1-2 tectonism. As an effect of doming, the relative movement along the low-dip L1 or L1-2 mineral/stretching lineation has been inverted and became apparently left lateral in the WNW flank of the dome (Figure 19a) and right lateral in the eastern flank (Figures $19 \mathrm{~b}$ and $19 \mathrm{c}$ ) with an average dip of $30^{\circ}$ to the south. (Figures 18a and 18c).

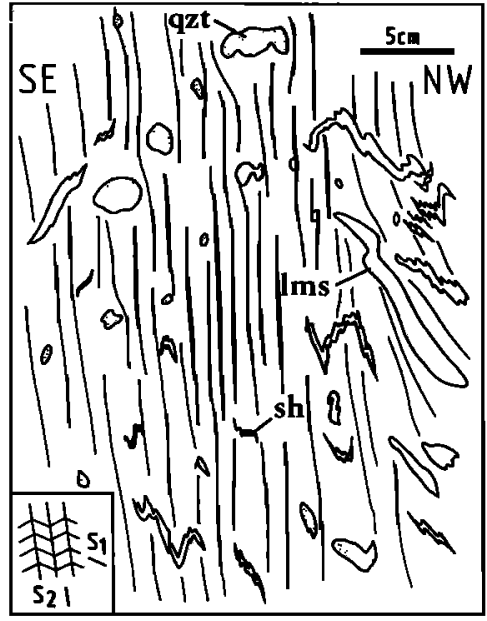

Fig. 10. Schistose diamictite in a large, SE facing, F2 fold (Poeun unit, $7.5 \mathrm{~km}$ east of Daejeon). The S2 strain slip cleavage cuts across the $S 1$ foliation with microfolding of the previously stretched limestone and shale clasts.

\section{EVIDENCE FOR A MIDDLE PALEOZOIC TECTONIC PHASE IN THE OGCHEON BELT: THE "OGCHEON TECTONISM"}

The late Paleozoic Pyeongan Group is formed of a threefold sequence composed of (1) paralic formations at the base (reddish shale and sandstone and thin bioclastic platform limestone) (upper middle Carboniferous to Early Permian), (2) limnic coal-bearing shale and sandstone in the middle part (Middle Permian), and (3) thick terrestrial siliclastic rocks in the upper part (Upper Permian to Lower Triassic). The low subsidence rate and uniform platform conditions that prevailed in late Paleozoic times sharply contrast with the "basinal" setting of early Paleozoic deposits (Ogcheon Supergroup). In addition, evidence for large neighboring emerged areas is provided by terrigenous material supply throughout the sequence.

As the Pyeongan Group is now restricted to the slightly deformed foreland of the early Paleozoic orogen, it never directly overlies the D1-2 thrust contacts at outcrop. Therefore, although previous structural studies provided some evidence for

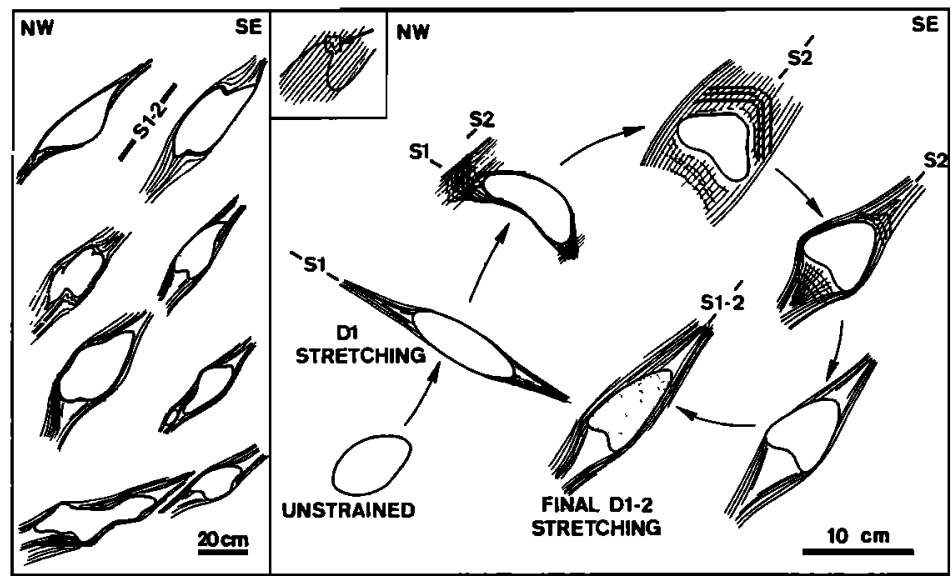

Fig. 11. Complex pebble patterns in S1-2 transposed foliation, and possible deformation path for a pitted and stretched quartzite pebble in the hinge zone of mesoscopic F2 fold. 


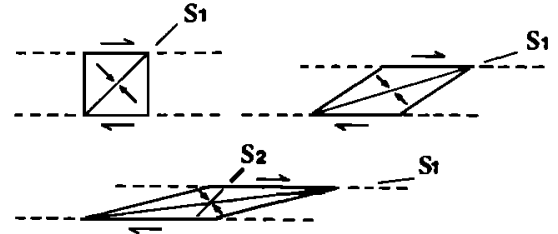

Fig. 12. Theorical relationship between shear strain and S2 foliation developed after $\mathbf{S 1}$ during progressive deformation. The finite strain has been arbitrarily chosen as a combination of pure shear and simple shear.

polyphase tectonics [Reedman et al., 1973; Kang and Chi, 1980; Kang et al, 1981; Choi and Kim, 1981; Lee and Park 1983; Kang et al., 1986; Chang, 1988a, 1988b; Lee and Kim, 1988; Song and Kim, 1988], tectonic structures were as a whole assigned to the Mesozoic, and the middle Paleozoic hiatus was interpreted as a result of gentle uplift [Kobayashi,
1953; Reedman and Um, 1975]. This is obviously true in the Taebaeksan region (Figure $1 \mathrm{~b}$ ) where the Middle Ordovician is disconformably overlain by middle or late Carboniferous paralic deposits without perceptible clino-unconformity. In contrast, several lines of evidence demonstrate that in other places of the Ogcheon belt, i.e. to the west of Honam Shear Zone [Yanai et al., 1985; Cluzel, 1989a, 1991] (Figure 1), a major tectonic phase took place before the middle Carboniferous as outlined below.

\subsection{Angular Unconformity at the Base of the Late Paleozoic Pyeongan Group}

It is a well known fact that the Duwibong sequence of the Joseon Supergroup (Cambrian to Middle Ordovician) (Figure 2) and the Pyeongan Group (upper Middle Carboniferous to Lower Triassic) have paracomformable relations in the Taebaeksan region (the autochthonous cover of the Ryeongnam block) [Kobayashi, 1953]. As a matter of fact, the Ryeongnam block is a separated piece of the North China-North Korea

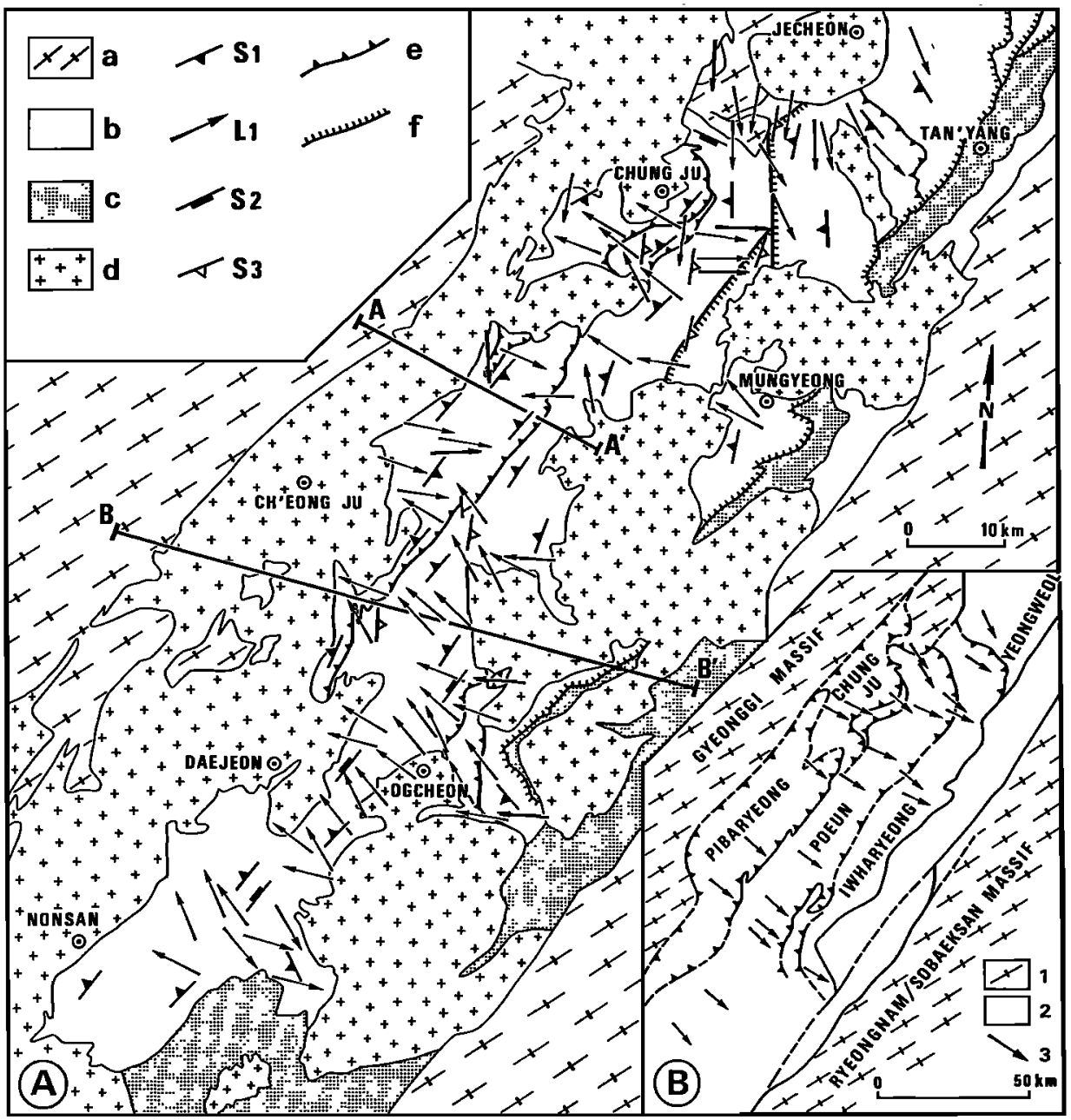

Fig. 13. Regional pattems of the D1-2 tectonism. (A) Structural map of the central Ogcheon belt. Legend: a, Archaean- middle Proterozoic basement; b, early Paleozoic; c, post-middle Carboniferous sediments; d, Mesozoic granitsids; e, S1 foliation; $f$, bearing and plunge of the stretching lineation , $g$ : S2 foliation, h : S3 foliation; i, main ductile (D1-2) thrust; $\mathrm{j}$, reverse faults or high angle thrusts. A-A' and B-B', location of profiles, Figure 14. (B) Sketch map of the same area (Mesozoic granites omitted). 1, Precambrian basement; 2, Early Paleozoic; 3, restored bearing and relative motion along the L1-2 stretching lineation prior to D3. 

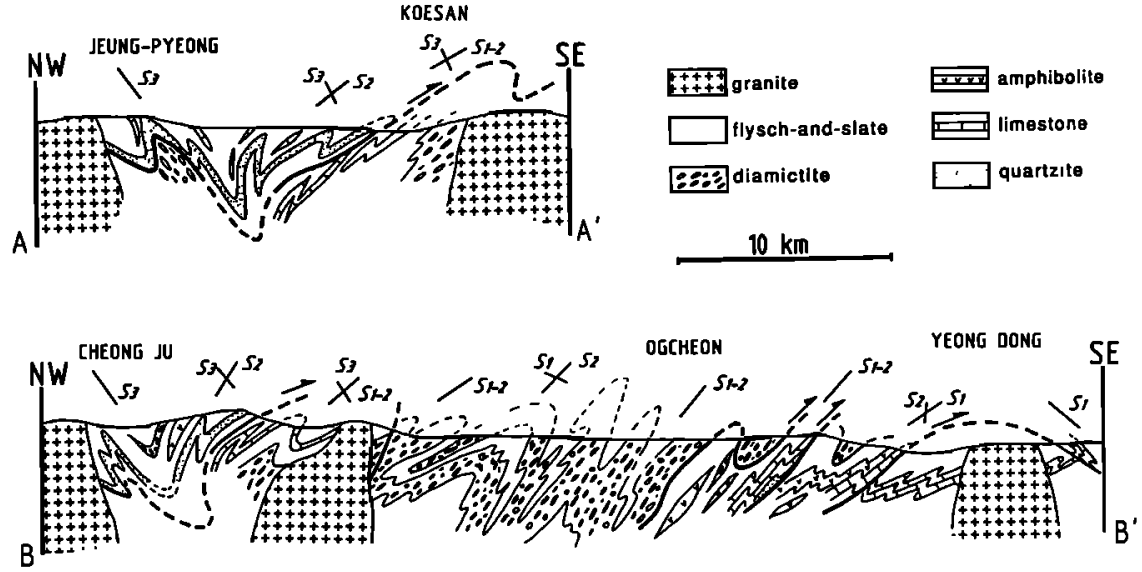

Fig. 14. Composite cross sections of the central Ogcheon belt (vertical scale exaggerated). Two-phase southeast directed thrusting and associated F1 and F2 folds are related to the initial stacking of the nappes to the southeast (the middle Paleozoic D1-2 "Ogcheon" tectonic phase). The F3 backfolding to the WNW is due to the subsequent Indosinian (middle to late Triassic) tectonic phase (D3) (for location, see Figure 13).

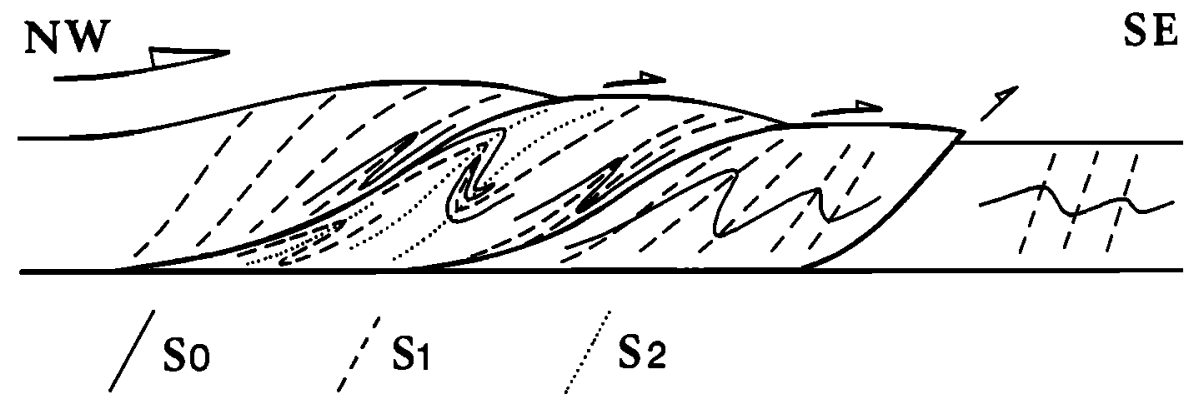

Fig. 15. Idealized cross section of a hinterland dipping duplex showing the foreland weakening of shearing deformation and progressive development of D1 and D2 structures in medial units during one tectonic episode.
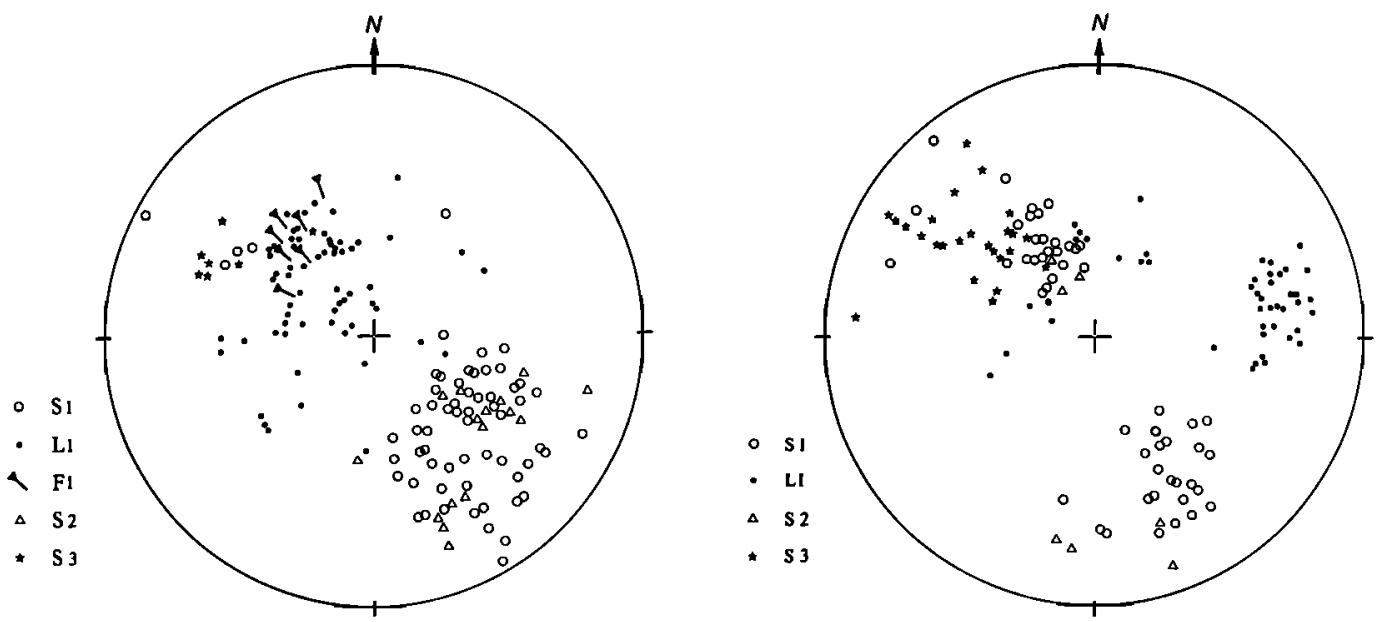

Fig. 16. Stereoplots (Wulf net, lower hemisphere) of selected structural elements of the Ogcheon belt. (A) Daejeon-Ogcheon-Poeun area. Note the occurrence of F1 fold axes parallel to the average trend of the L1 stretching lineation (A-type folds), the folding of S1 and L1 by F2 homoaxial folds and the occurrence of S3, steeply dipping to the SE or to the ESE. (B) Chung Ju-Tan'yang area. The most prominent feature is due to F3 folds with NNE-SSW trending S3 axial plane foliation that have refolded S1 and S2 and reoriented L1 from NW-SE to WNW-ESE. 

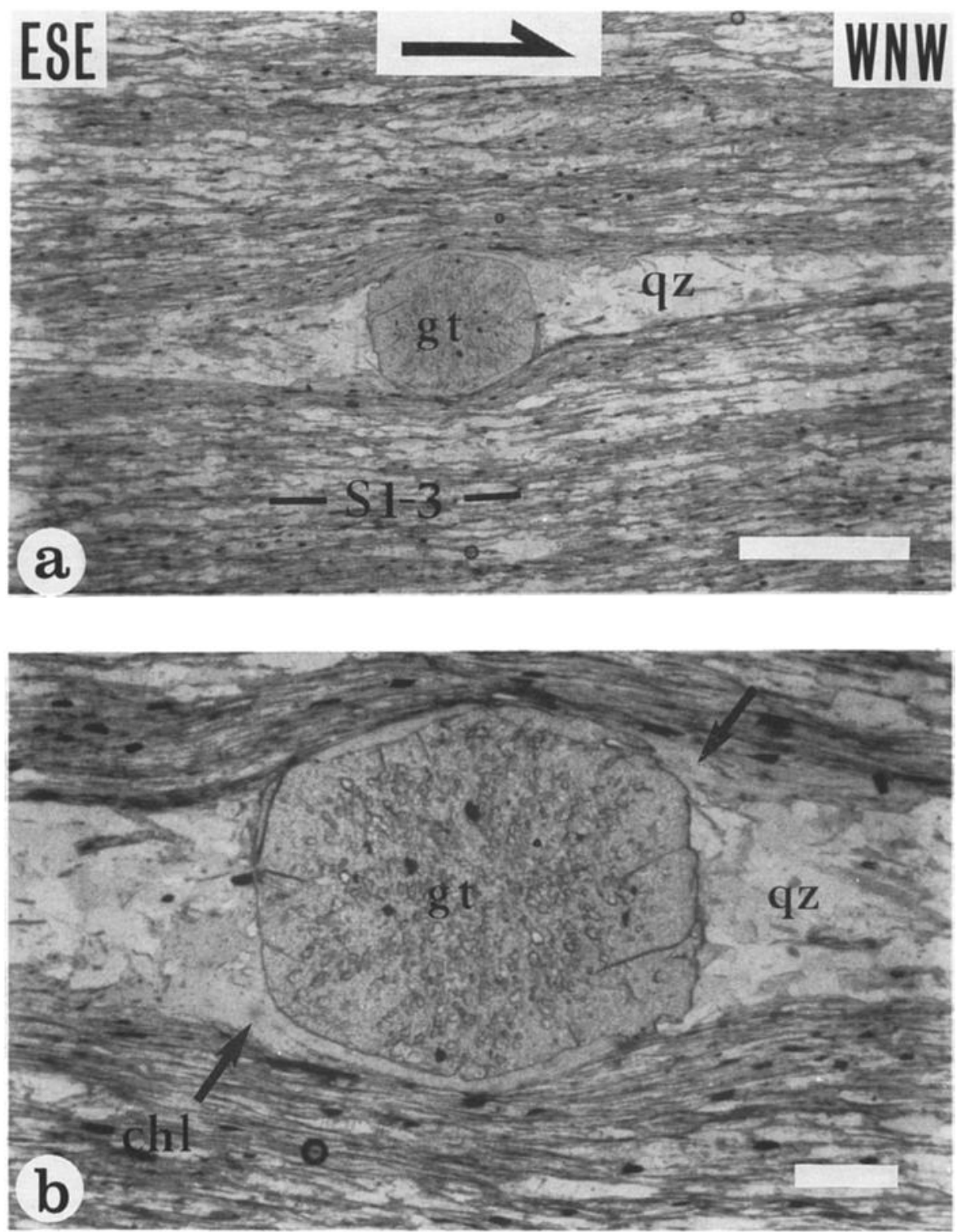

Fig. 17. Microstructures related to the D3 tectonic event (middle Triassic). (a) L3 asymmetric quartzchlorite pressure shadows around unrotated prekinematic garnet indicating incipient WNW directed shearing (section parallel to L3 and perpendicular to the composite S1-3 foliation, gamet-biotitemuscovite mica schist, Pibanryeong unit, $10 \mathrm{~km}$ SW of Koesan) (scale bar: $5 \mathrm{~mm}$ ). (b) An enlarged view of the same garnet crystal shows asymmetric chlorite "tails" (arrows) on opposite sides of the garnet and unarranged inclusions indicating that the garnet is prekinematic in regard to S3 (scale bar: $1 \mathrm{~mm}$ ). (c) A section of the same sample, perpendicular to the composite foliation and parallel to the inferred NW-SE direction of the Ll stretching lineation, shows that the garnet porphyroblasts display clockwise sigmoidal inclusion trails indicating SE directed shearing related to D1 or D1-2 (scale bar: $1 \mathrm{~mm}$ ). (d) Syn-kinematic, D3 related, andalusite porphyroblast displays anticlockwise rotation, indicating WNW directed shearing (composite S1-3 foliation, Poeun unit, $8.5 \mathrm{~km} \mathrm{SW}$ of Ogcheon)(scale bar: $1 \mathrm{~mm}$ ).

[Sino-Korean] platform [Cluzel, 1989a] where middle Paleozoic tectonism is lacking.

On the other hand, in other areas of the Ogcheon belt, the Pyeongan Group rests uncomformably upon older rocks [Geological Society of Korea, 1966]. Angular uncomformities between Pyeongan Group and early Paleozoic rocks have been reported in the Hwasun coalfield [Reedman and Hwang, 1975] and in the Tan'yang, Mungyeong and Jecheon areas; near
Poeun, Carboniferous conglomeratic sandstone rests directly upon Precambrian gneisses and early Paleozoic limestone [Lee and Cluzel, 1988]. The basal conglomerates are usually thin and laterally impersistent, but locally (Tan'yang), they are represented by an unconformable olistostromelike conglomerate derived from the underlying early Paleozoic limestones and Precambrian basement [Lee and Cluzel, 1988]. The occurrence of unconformity and distal basal conglomerate 

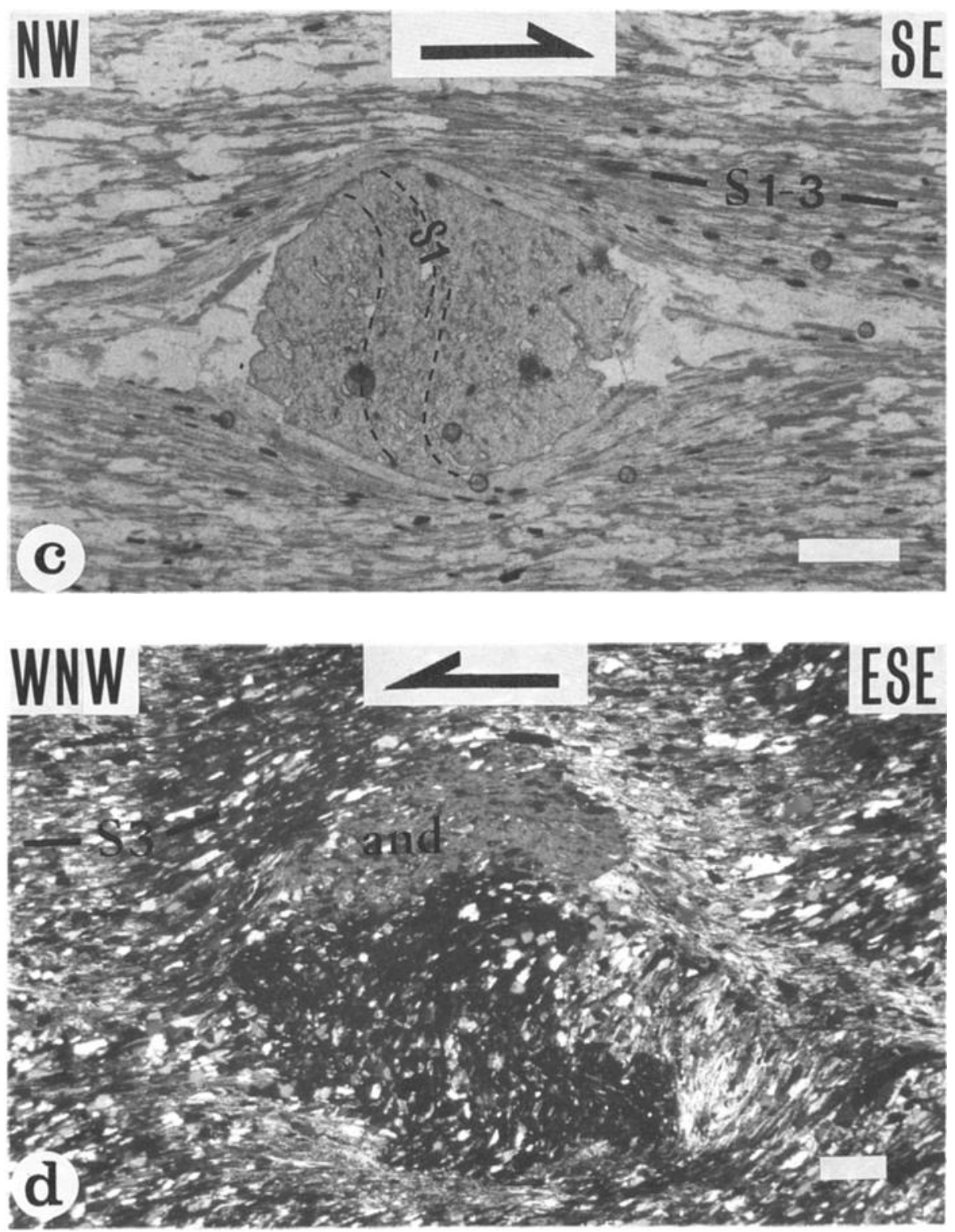

Fig. 17 (continued)

reveals that in contrast with previous interpretations of the Ogcheon belt, a tectonic phase took place before the Middle Carboniferous.

\subsection{Post-Middle Silurian Paleogeographic Evolution}

Until recently, the Paleozoic deposits in Korea were as a whole attributed to a platform environment [Kobayashi, 1953], therefore no major paleogeographic change was supposed to occur during the Cambrian-Triassic period [Kobayashi, 1953; Reedman and Um, 1975]. Nevertheless, the evidence for an early Paleozoic age of the Ogcheon Supergroup [Lee et al., 1972; Kim, 1986; Lee J.H., 1987; Lee J.H. et al., 1989] imply that the early and late Paleozoic paleogeographies were quite different.

According to the paleogeographic model described above, the early Paleozoic formations display important lateral variations of facies related to different depositional and structural settings in the rift (see section 2). The huge debris flow deposits and associated alkalic or transitional tholeiitic volcanics are the most prominent features of the Ogcheon basin. They are clearly related to a major taphrogenic event, and mass flow sedimentation was likely generated by slope instability related to block tilting along large normal faults; in addition, the generation of large amounts of basic lavas in an intracontinental setting may be due to a mantle/thermal anomaly implying significant crustal thinning [Cluzel et al., 1989, 1990].

In contrast, the middle Carboniferous transgression started over a wide area with remarkably uniform reddish shales and associated sandstones (the "Hongjeom Formation"). Repeated intercalations of thin shallow water marine limestone beds illustrate that uniform platform conditions prevailed in the basin. It may be considered that an important tectonic phase closed the rift domain. Later, after a period of emersion and erosion (Devonian (?)-early Carboniferous), the Sino-Korean 


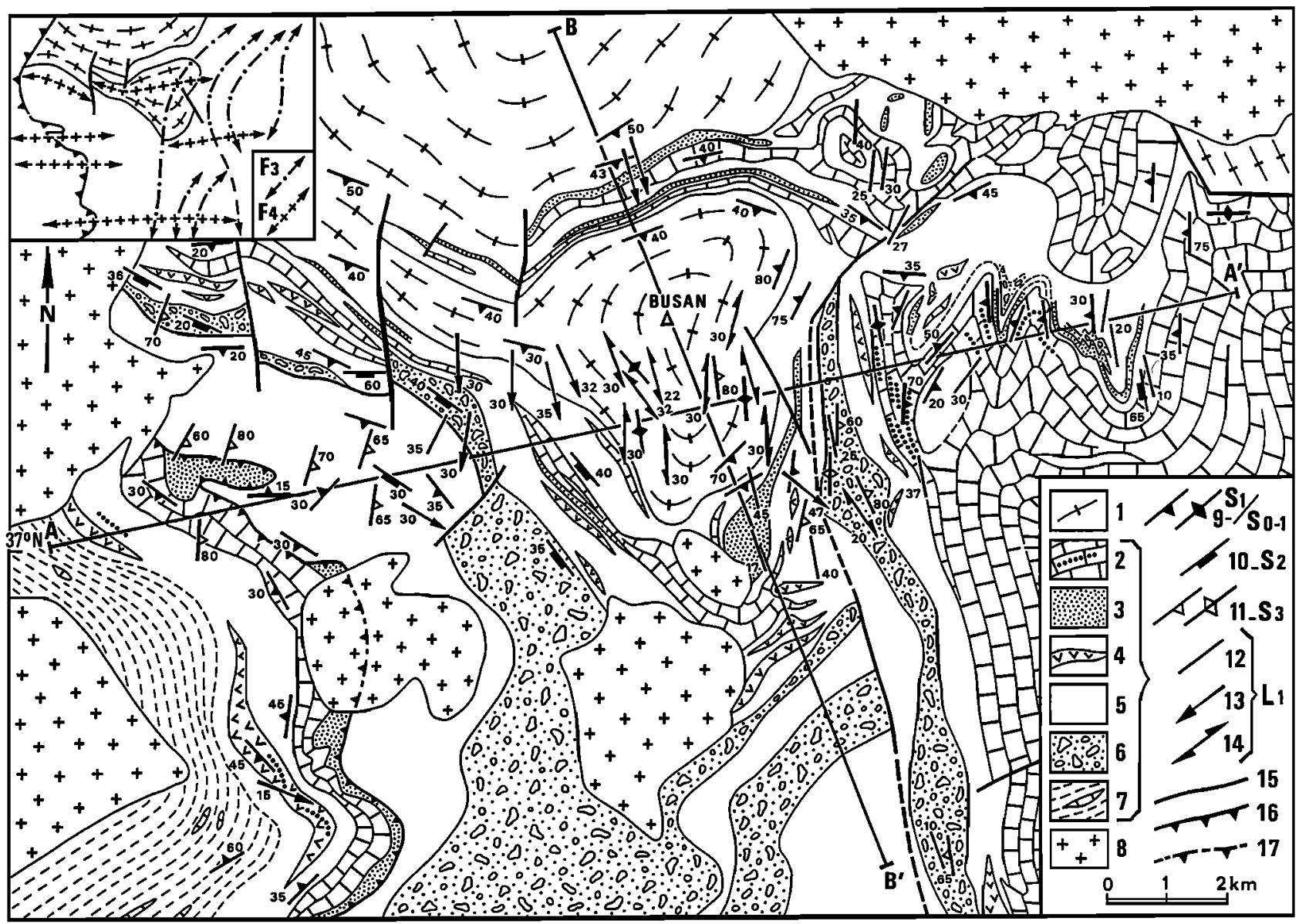

Fig. 18a. Geologic map of the large interference zone to the SW of Jecheon, adapted (and partly remaped) from the 1:50,000 geologic map of Korea, Chung Ju, Hwanggangni, and Jecheon quadrangles.

The Busan gneiss dome and Chung Ju synform result from F3 and F4 interferences (see insert). (for location, see Figure 2). 1 : Precambrian basement; 2-7: Ogcheon Supergroup including: 2, limestones with debris flow deposits interbedded at the top; 3 , quartzite; 4, metavolcanics; 5 , schists or carbonaceous schists; 6, debris flow deposits; 7, flyschoids with limestone olistoliths; 8, Mesozoic granites; 9, S1 or S0-1 foliation (symmetrical symbol = vertical foliation); 10, S2 foliation; 11, S3 foliation (symmetrical symbol = vertical foliation), 12-14 : stretching lineation (the angle of plunge is indicated on the down dip side of the bar) including: 12, stretching lineation without indication of the sense of shear; 13 , Stretching lineation (angle of pitch $>45^{\circ}$ ) the arrow indicate relative motion of the upper block; 14 , stretching lineation (pitch $\left\langle 45^{\circ}\right.$ ) with indication of wrench motion; 15 , fault; 16 , D1 thrust; 17 , concealed thrust. $\mathrm{AA}^{\prime}$ and $\mathrm{BB}^{\prime}$ sections are given in Figure $18 \mathrm{~b}$.

domain was the setting of predominantly terrigenous platform sedimentation. The final emersion of the Sino-Korean domain occurred in Middle Permian times and the subsequent evolution was purely intracratonic. Therefore we infer that the middle Paleozoic tectonism was responsible for the definitive amalgamation of the blocks into a single continental domain.

\subsection{Polyphase Tectonism in the Ogcheon Belt, Evidence for a pre-Carboniferous Tectonic Phase}

Within the Carboniferous-Permian Pyeongan Group, which is mainly located in the NE part of the belt (Figure 2), two tectonic phases are recognized instead of four. The first-phase folds are synfolial and strike $\mathrm{N} 20^{\circ} \mathrm{E}$ on average. Eroded first phase folds in the Pyeongan Group are unconformably covered by late Triassic coarse clastics [Barrier et al., 1989; Cluzel, $1989 \mathrm{~b}]$, or sharply crosscut by the faulted boundaries of the
Late Triassic basins [Choi and Kim, 1981] and by Late Triassic granitoids [Kim, 1987]; therefore they correspond to the mid-Triassic Indosinian tectonism. They are coeval to the F3 folds in the Ogcheon Supergroup, and their axial plane foliations identically display syntectonic crystallizations that are diagnostic of a low pressure metamorphic event (andalusite, cordierite, garnet, chloritoid).

Indosinian folds are upright or slightly recumbent to the WSW in the central part of the belt. To the east of a N-S line going through Jecheon, the folds become progressively recumbent to the ESE, in connection with WNW dipping high angle thrusts or reverse faults. In the Taebaeksan region, to the NE of the Ogcheon belt, and especially in the area located between Tan'yang and Samcheog (Figure 2), the folds are ESE facing whereas the intensity of deformation and metamorphic grade progressively decrease toward the ESE.

The axial planes of first-phase folds and associated thrusts are 

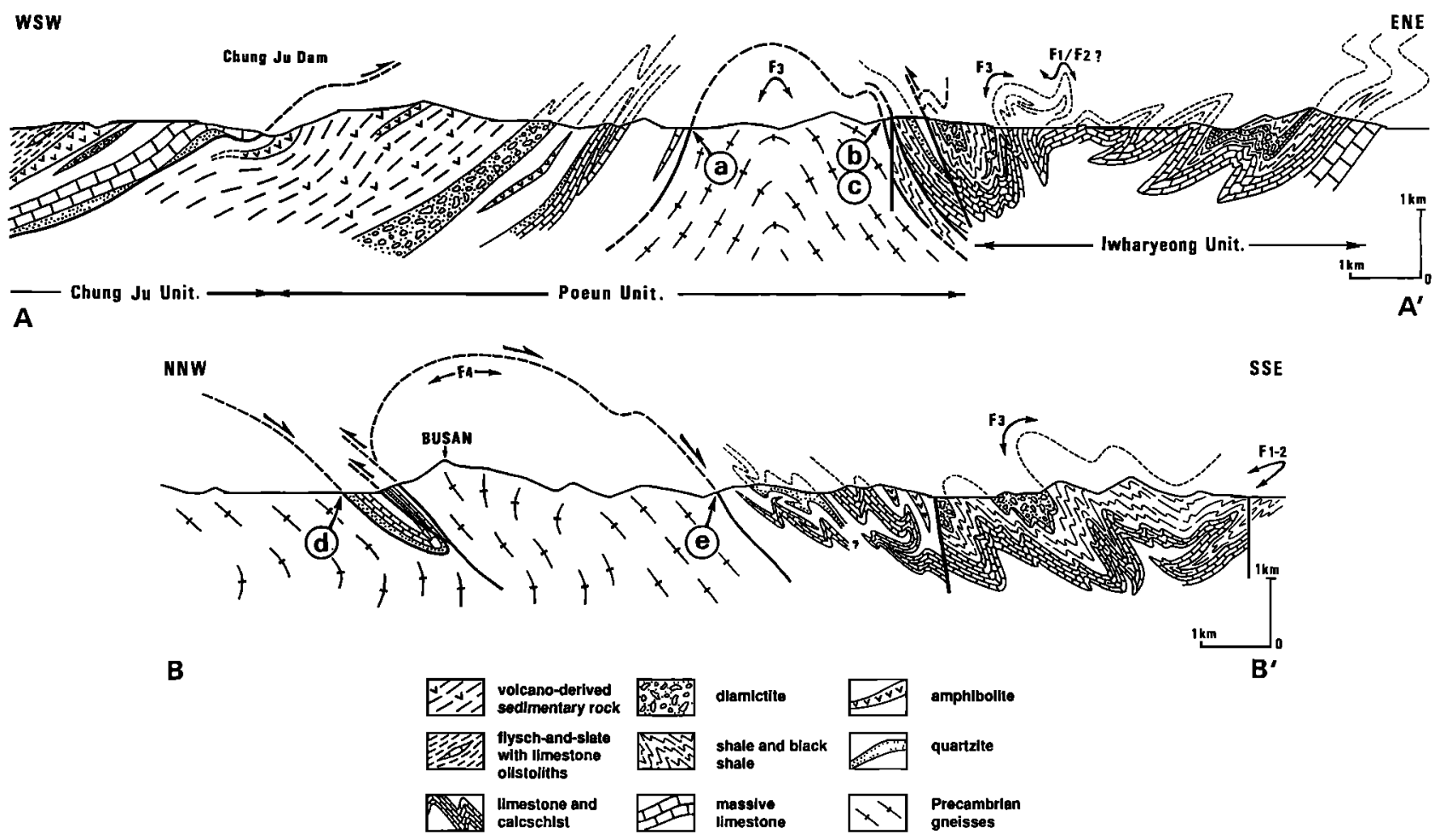

Fig. 18b. N-S and E-W cross sections of the Busan gneiss dome area (for location, see Figure 18a); circle-labeled arrows (a-d) refer to plates (Figure 19).

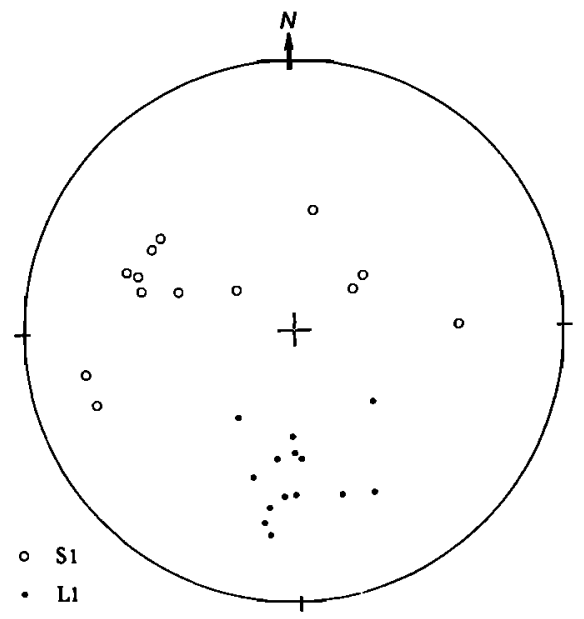

Fig. 18c. Stereoplot of the structural elements on the southern part of the Busan dome. The mylonitic foliation that formed an antiform (F3) with steeply dipping flanks bears a prominent stretching lineation that originally indicated southeast directed relative motion (Wulf net, lower hemisphere).

branched downward into NE-SW trending right lateral wrench faults (Jeongseon coalfield). The association of wrench faults, en échelon upright folds, and related high angle thrusts displaying "positive flower structures" is a well-known tectonic feature due to compressive bridges located in relay zones between parallel wrench faults. The NE-SW trending dextral faults are related to the Honam Shear Zone whose age is constrained by uppermost Triassic synkinematic and postkinematic granitoids [Cluzel 1989a; Cluzel et al., 1991]. Therefore it may be considered that the intracratonic Middle to Late Triassic Indosinian tectonism in the Ogcheon belt (the Songnim disturbance of previous authors) is related to a regional ESE-WNW directed "transpression" regime [Cluzel, 1989a], that is, clearly different from the D1-2 tectonic event described above.

The first-phase synfolial folds in the Pyeongan Group are refolded by subsequent (post-Liassic) E-W trending, open to gentle postfolial folds (F4 in the Ogcheon Sgr.) [Barrier et al., 1989; Cluzel, 1989b]; refolding pattems are spectacularly exposed between Tan'yang and Samcheog and in the northeasterly termination of Ogcheon belt between Jecheon and Gangneung.

In the Yeongweol unit, SE of Jecheon and in Tan'yang area, Ordovician limestones that bear the SO-1 foliation and L1 lineation, are unconformably overlain by middle Carboniferous shales, sandstones and limestones (Gabsan formation). The subvertical, $\mathrm{N}-\mathrm{S}$ trending, axial plane foliation of the Indosinian folds cuts across the flat lying S0-1 foliation in geometrical continuity below the unconformity. The crosscutting foliation is coeval to $S 3$ in more internal units. As the D1-2 deformation is lacking in the Pyeongan group, it may be inferred that the corresponding SE directed ductile stacking is related to a post-Middle Silurian--pre middle Carboniferous tectonic event, the "Ogcheon orogeny" or tectonism [Kim, 1987; Cluzel, 1990].

In Late Triassic basins (Daedong Supergroup) two phases of deformation are present [Reedman and Um, 1975; Kang et al., 1986]. The first one is represented by NE-SW trending open 

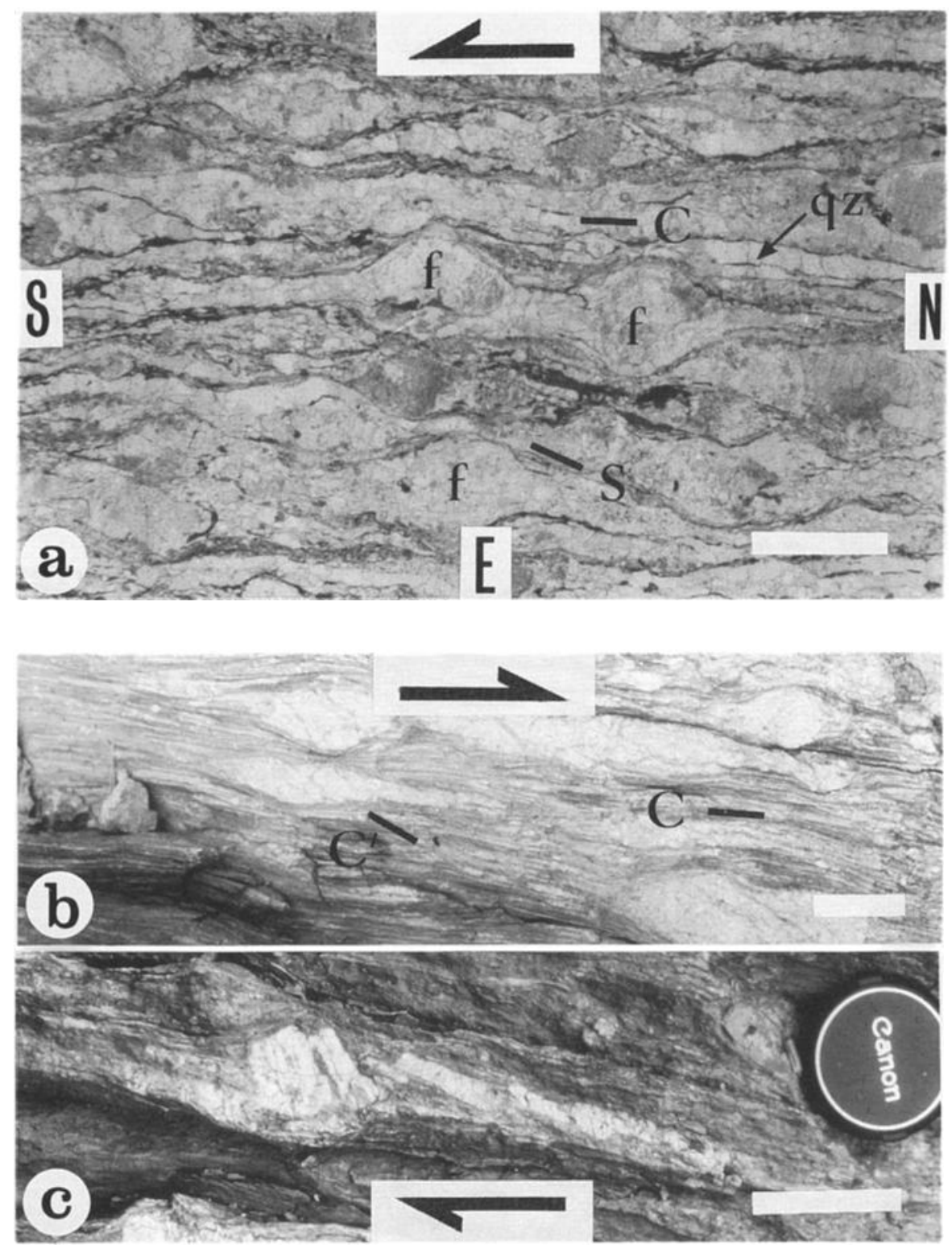

Fig. 19. Microstructures of the Busan gneiss dome (It is important to note that the mylonitic foliation is overprinted on the pre-existing gneissosity) (for location see cross sections in Figure 14b). (a) Sinistral S-C fabrics in augen gneiss, vertical mylonitic foliation trending N-S, western flank of the Busan dome (scale bar: $5 \mathrm{~mm}$ ). (b) Ductile dextral fabrics on vertical foliation trending $\mathrm{N}-\mathrm{S}$, eastern flank of the Busan dome (outcrop picture) (scale bar: $1 \mathrm{~cm}$ ). (c) A more brittle behaviour of this broken and displaced feldspar phenocryst may be related to a late stage of the shearing deformation; location approximately same as $18 \mathrm{~b}$ (outcrop picture) (scale bar: $5 \mathrm{~cm}$ ). (d) Phyllonite from SE dipping basement biotite micaschists from the northern backthrusted flank of the Busan dome (scale bar: $1 \mathrm{~mm}$ ). (e) S-C mylonite from augen gneiss from the southem flank of the Busan gneiss (scale bar: $10 \mathrm{~mm}$ ).

folds associated with high-angle imbicated thrusts. The relative motion along the thrust planes is NW over SE as marked by slickensided surfaces. The second phase is represented by E-W trending gentle folds that generate dome and basin interference structures while the preexisting thrusts are reactivated as leftlateral faults with an important vertical component indicating south directed reverse motion; in places, small-scale flexural folds and kink folds with subvertical axes, closely related to the limiting faults of the Daedong basins, have been most likely generated during this tectonic event.

In the Ogcheon Supergroup, the first post-Liassic phase is not easily decipherable because its kinematic axes are parallel to those of the D1-2 tectonism and close to those of D3. In contrast, the F4 gentle folds obviously correspond to the second post-Liassic phase marked by E-W trending folds (see Table 1). 

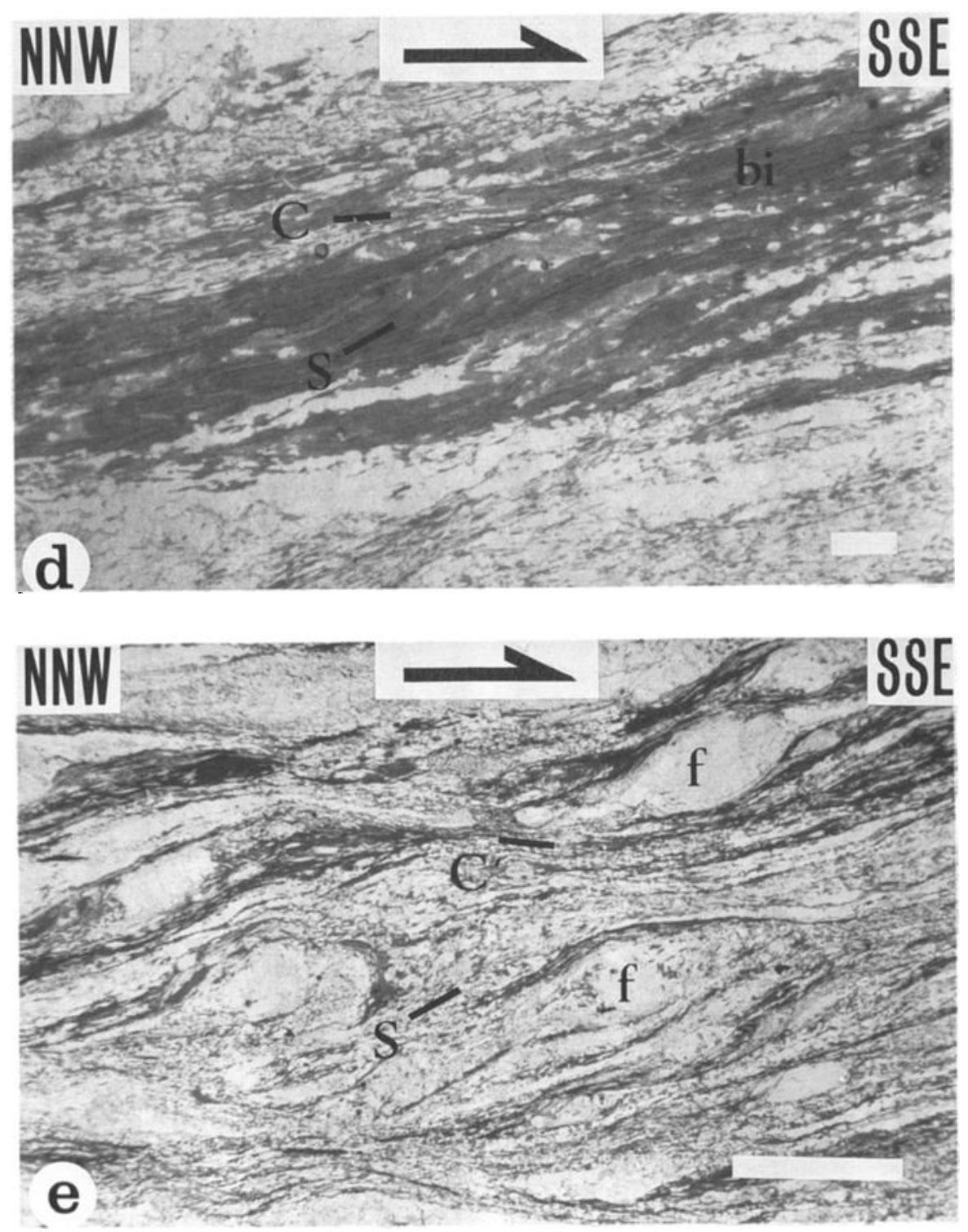

Fig.19 (continued)

\subsection{Radiometric Evidence for a Middle Paleozoic Tectonometamorphic Event}

The Ogcheon belt obviously underwent several superimposed metamorphic phases. Regardless of the isotopic reseting due to Jurassic and Cretaceous granite emplacement, three main tectonometamorphic events have been recognized: (1) Middle to Late Jurassic [Kim, 1971], (2) Middle to Late Triassic [Cliff et al, 1985], and (3) Early Devonian [Kim, 1987].

The wide range of the K-Ar data obtained from micas and amphiboles (500-150 Ma) [Yun, 1983; Hong and Choi, 1986; Oh, 1986; Kim, 1987] appears to be a consequence of the discontinuous character of the Jurassic reseting. Actually, during the Middle to Late Jurassic tectonism, the thermal effects appear to be restricted to the vicinity of large reactivated basement faults and granitoid plutons.

The Indosinian metamorphism (circa 240-210 Ma) was first evidenced in the meta-diamictites of the Ogcheon Supergroup east of Chung Ju by the Rb-Sr whole rock method [Cliff et al.,
$1985]$ and by the ${ }^{39} \mathrm{Ar}-{ }^{40} \mathrm{Ar}$ method in amphiboles from metadolerites of the volcanic complex [Lee, 1988].

Recently, an early Devonian isochron (392 $\pm 13 \mathrm{Ma}$ ) was obtained by the $\mathrm{Rb}-\mathrm{Sr}$ whole rock method from the medium grade uraniferous metasediments of the Poeun unit to the southwest of Chung Ju (Koesan) [Kim, 1987, 1989].

Although more data are needed, this result suggests that in the internal zone of the Ogcheon belt, a well-defined early middle Paleozoic metamorphic event may be related to the preCarboniferous tectonism inferred from structural and stratigraphic evidence.

\section{DISCUSSION}

\subsection{A Model of Tectonic Inversion of the Early Paleozoic Ogcheon Rift}

On the basis of the above mentioned evidence, the D1-2 tectonic phase appears to be related to the pre-Carboniferous 
TABLE 1. Tecınic Features in the Four Main Straligraphic Units of the Ogcheon Belt and Evidence for a Polycyclic Evolution

\begin{tabular}{|c|c|c|c|c|c|}
\hline & \multicolumn{2}{|c|}{ Pre- Carbonferous } & \multirow{2}{*}{$\begin{array}{c}\text { Middle to Late Triassıc } \\
\text { D3 } \\
\end{array}$} & \multicolumn{2}{|c|}{ Post- Liassic } \\
\hline & D] & D2 & & D4 A & D4 B \\
\hline Basement & $?$ & $?$ & dextral ductile faults & $?$ & E-W open folds \\
\hline \multicolumn{6}{|l|}{ Rift } \\
\hline $\begin{array}{l}\text { Ogcheon } \\
\text { Supergroup }\end{array}$ & $\begin{array}{l}\text { recumbent isoclinal F1 } \\
\text { "A" lype or sheath } \\
\text { folds, genuly dip- } \\
\text { ping S1, Ll } \\
\text { (SE directed shear) }\end{array}$ & $\begin{array}{l}\text { 1soclınal or light F2 } \\
\text { overtumed to the } \\
\text { SE, S2 or S1-2 (dip- } \\
\text { p1ng to the NW), } \\
\text { (SE directed shear) }\end{array}$ & $\begin{array}{l}\text { open to tight F3, } \\
\text { overturned to the } \\
\text { WNW, S3 steeply dip- } \\
\text { ping to the ESE, L3 } \\
\text { (WNW directed shear) }\end{array}$ & not decipherable & $\begin{array}{l}\text { bending of F3 fold } \\
\text { axes, E-W F4 open } \\
\text { folds, interference } \\
\text { suructures }\end{array}$ \\
\hline \multicolumn{6}{|l|}{ Plauform } \\
\hline $\begin{array}{l}\text { Joseon } \\
\text { Supergroup }\end{array}$ & NE-SW & open folds & $\begin{array}{l}\text { open folds (locally } \\
\text { F2) NNE-SSW axes }\end{array}$ & $\begin{array}{l}\text { folds not decipherabl } \\
\text { SE directed thrust } \\
\text { (britlle) }\end{array}$ & $\begin{array}{l}\text { E-W open folds, } \\
\text { dome-and-basin inter- } \\
\text { ference structures }\end{array}$ \\
\hline $\begin{array}{l}\text { Pyeongan } \\
\text { Group }\end{array}$ & $x x$ & $x x$ & $\begin{array}{l}\text { open to tight folds } \\
\text { NNE-SSW axes } \\
\text { high angle thrusts }\end{array}$ & $\begin{array}{l}\text { folds not decipherabl } \\
\text { SE directed thrust } \\
\text { (brittle) }\end{array}$ & $\begin{array}{l}\text { E-W gentle folds, } \\
\text { sinistral wrench } \\
\text { thrusts, dome-and- } \\
\text { basin interference } \\
\text { structures }\end{array}$ \\
\hline $\begin{array}{l}\text { Daedong } \\
\text { Supergroup }\end{array}$ & $\mathrm{xx}$ & $\mathrm{XX}$ & syntectonic basins & $\begin{array}{l}\text { NE-SW folds, } \\
\text { SE directed thrust } \\
\text { (brittle) }\end{array}$ & $\begin{array}{l}\text { E-W gentle folds, or } \\
\text { with verucal axes, } \\
\text { sinustral wrench } \\
\text { thrusts, dome-and- } \\
\text { basin interference } \\
\text { structures }\end{array}$ \\
\hline Granites & & $\gg \gg ? \gg>$ & 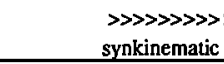 & 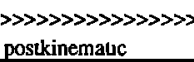 & 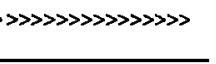 \\
\hline
\end{tabular}

ductile thrusting of the nappes that composed the Ogcheon Supergroup. The $S 1$ foliation was generated by the subhorizontal shearing due to the initial stacking toward the SE. The S2 strain slip cleavage recorded the subsequent shortening of the medial units contemporaneous with the thrusting of the uppermost ones.

As in many orogens, the main tectonic units correspond to distinct paleogeographic zones of the initial basin. The outermost Jeongseon and Yeongweol units correspond to the southeastern relatively stable platform; the Iwharyeong, Poeun, and Turungsan units represent the faulted margin of the basin, transitional between the platform and the basin itself and marked by volcanic activity and synsedimentary slope instability; the innermost Chung Ju and Pibanryeong units represent the "basinal" domain of the rift. Thus it is possible that the synsedimentary extensional faults were reactivated as thrusts during the Late Silurian-Early Devonian compressional tectonism. Tectonic inversion [e.g., Ziegler, 1978; Bally, 1984; Coward and Ries, 1986; De Gracciansky et al., 1988] of the Ogcheon rift resulted in a stack of nappes which originated from contrasting paleozones of the early Paleozoic basin (Figure 20).

The previous authors [Kim, 1970; Reedman and Um, 1975; Hong, 1984] postulate Mesozoic monophase metamorphism; therefore mineral associations related to the D1-2 and D3 tectonometamorphic events were apparently undifferentiated in establishing metamorphic isograds. Actually, according to our microstructural analysis, and in spite of Indosinian overprint, it appears that only medium pressure type parageneses are related to the D1-2 tectonism.

It is worth noting that, in spite of many petrographic studies, no evidence for high-pressure metamorphism was reported (see, for example, $\mathrm{Na}$ [1986]). Our data confirm this point.

On the basis of stratigraphic and radiometric evidence, the Ogcheon rift basin was affected by compressive tectonism soon after it was formed. Medium pressure-medium temperature regional metamorphic conditions are consistent with the early closure of an aborted intracontinental rift that involves the overstacking of a previously thinned (i.e., hot) continental crust.

One of the remaining problems is the apparent lack of postcollisional magmatism. Nevertheless, the recent development of systematic $\mathrm{Rb}-\mathrm{Sr}$ whole rock radiometric method reveals that some of the orthogneisses previously related to the Precambrian basement may be actually middle Paleozoic "S type" granitoids (Jangkye orthogneiss : $370 \pm 30 \mathrm{Ma}$, $\left.\left({ }^{87} \mathrm{Sr} /{ }^{86} \mathrm{Sr}\right)_{\mathrm{i}}=0.7111 \pm 0.0003\right)$ [Choo and $\mathrm{Kim}, 1986$ ].

Thus, contrary to the assumptions of many authors (see, for example, Hsü et al. [1990]) who postulated the occurrence of ophiolite remains and tectonic melanges, the early Paleozoic tectonism in the Ogcheon belt presents all the characteristics of an "ensialic" orogeny (without oceanic suture) that was originated by the closure of an intracontinental rift basin and the subsequent collision of its margins (Figure 20).

\subsection{Regional Correlations}

Due to insufficient data, correlations with adjacent areas remain conjectural. Some authors speculatively propose an extension of the Qinling belt east of Tanlu fault, south of the Shandong peninsula, with a sinistral offset of some $500 \mathrm{~km}$ [Xu et al., 1987] (Figure 1). Such an extension may likely continue into the pre-Carboniferous Imjingang belt in central Korea rather than in the Ogcheon belt (although Mesozoic wrench faults prevent any direct correlation).

Nevertheless, at present there is no evidence for a large orogen similar to the Qinling belt east of Tanlu fault. Evidence for the subduction of a wide oceanic area is scarce (Shandong peninsula ?), or completely lacking (Imjingang belt), in spite of assertions of some authors who interpreted this latter zone as an oceanic suture [Klimetz, 1987].

Owing to the paleobiogeographic correlation of its southeastern paleomargin (the Yeongweol/Jeongseon units) with the 
(A)

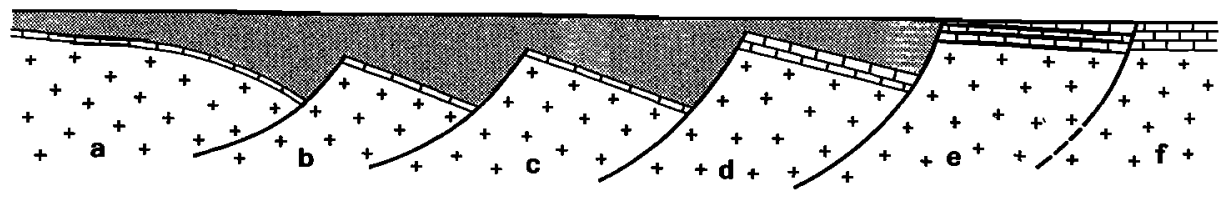

(B)

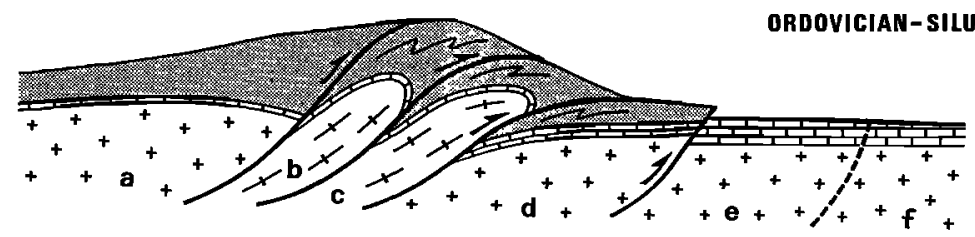

(C)

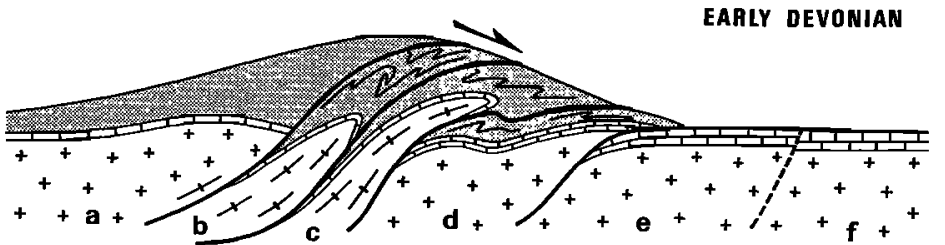

EARLY DEVONIAN (continued)

(D)

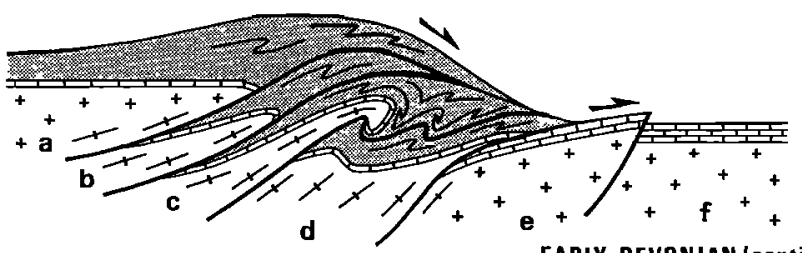

EARLY DEVONIAN (continued)

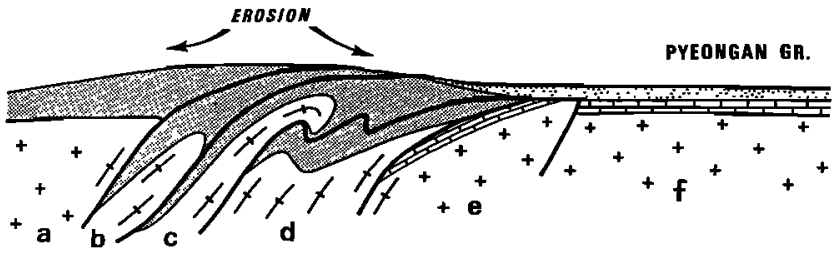

(E)

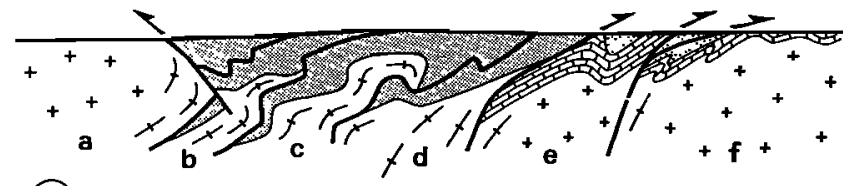

(F)

D3 (MIDDLE TRIASSIC)
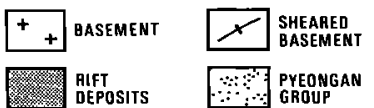

PLATFOAM
DEPOSITS

Fig. 20. Simplified palinspastic reconstruction and tectonic evolution of the Ogcheon belt from early Paleozoic to Middle Triassic times. The early stages of the middle Paleozoic Ogcheon orogeny are tentatively represented by the tectonic inversion of the early Paleozoic extensional features of the rift; thereafter, the nappes that represent the inner paleozones of the basin have been folded and thrust to the SE while the external platform units remain almost unfolded. In middle to late Palcozoic times, erosion occurred in the inner part of the belt and Carboniferous to Early Triassic "molasses" were deposited in the moderately subsiding foreland of the belt. The final stage is represented by the Middle Triassic transpressive tectonics that resulted in fan-shaped F3 folding and extensive strike-slip faulting.
Jiangnan subprovince in the Cambrian [Kobayashi, 1966], it is likely that the Ogcheon rift may be correlated westward with a domain located in between the Yangtze and Jiangnan subprovinces of the Yangtze plate. It is noteworthy that if the Jiangnan and Yangtze subprovinces have similar CambrianOrdovician sequences [although Jiangnan sequence is thicker] and identical Cambrian trilobite faunas, their Ordovician faunas become distinct, together with the development of bathyal sedimentary facies (marine carbonaceous mudstones) [Yang et al., 1986]. Deepening of the Yangtze within-plate sedimentary basin is likely to be correlated with rifting in the Ogcheon area. The subsequent evolution of the Korean peninsula is purely intracratonic as marked by its sedimentary and tectonic characteristics. It was mainly dominated by the reactivation of pre- existing lineaments as a consequence of the peri-Pacific orogenesis.

Acknowledgements. The authors and particularly D.C. are greatly indebted to the President of the Korea Institute of Energy and Resources for welcome and logistical assistance during the past 5 years. Special thanks are also due to D.H. Kim, Vice-President of K.I.E.R. and members of the Geology Department for introducing the geology of Ogcheon belt and constant help during field work. M.P. Klimetz and an anonymous reviewer are also thanked for helpful comments and criticism of the manuscript. This study has been supported by the Institut Français du Pétrole and French Ministry of Foreign Affairs. 
REFERENCES

Bally, A.W., Tectogenèse et sismique réflexion, Bull. Soc

arricr, E., D. Cluzel, and J.P. Cadet, Les lectoniques mésozoiques en Corce : un exemple de déformation intraconti-
nenlialc nolyphasce, CR. Acad Sri . Parts, 30S, II, 793nentiale noly

Berthe, D., P. Choukrounc, and P. Jegouzo, Orthogneiss, mylontle and non-conxial deformauon of granites: the mylonile and non-coaxial deformaluon of graniles: the example of the South

Chang, T.W., Time relationships between the growth of

bioule porphyroblast and deformation, and the development of slaty cleavage in the metapelitic rocks of Ogcheon group. J. Geol Soc Korea, 24, 127-139, 1988:

Chang, T.W., Geologic structures and stratigraphy of Ogcheon

group in the southerm Ogcheon belt, J. Geol. Soc. Korea,

$24,340-355,1988 \mathrm{~b}$.

Choi, W.C. and D.H. Kim, The study of Ogcheon gea-

synclinal belt (I), Rep. Geosc. Miner. Res., Korea Inst.

Geol. and MLn., Seoul, Korea, VII, 19-43, 1981.

Choo, S.H., and S.J. Kim, A study of Rb-Si radiochronology ir: the Ryeongnam massif (III), Rep. 1986-2(17), pp. 1.28

Chough, S.K., Submarine debris fow deposits in the O.

basin, Korean peninsula, Techn. Bull, J4, pp. 17-29. United Nations Econ. and Soc. Comm. for Asia and the Pacif., Comm. Coord. Jount Prosp. Mmer. Resour. Asian Offshore Areas, 1981

Chun, H.Y., and S.H.Um, 1:2,000,000 geological map of Korea, Korea Inst. of Energy and Resour. Ed., Seoul, 1984. Cliff, R.A., G. Jones, W.C. Chol, and TJ. Lee, Strontum isotopic equilibration during metamorphism of tillites from the Orcheon belt, South Korea, Conirib. Mineral. Petrol 90. 346-352, 1985.

Cluzel, D., The polyphase Paleozoic-Mesozoic tectonism in the Ogcheon belt (South Korea), a collision model, Terro Cognila, 7, 116, 1987.

Cluzel, D.. La zone de cisaillement ductile de Honan (Corée du Sud) - Un décrochement dextre majeur au Tras supéneur. Consequences palcogégraphiques et struciurales, $C . R$. Acad. Sci. Paris, II, 308, 1521-1528, 1989a.

Cluzel, D., The Indosinian (Permian-Triassic) intracratonic tectorics in the Ogcheon Belt (South Korea), Terra Abstr. $1,, 367,1989 \mathrm{~b}$

Cluzel ,D., La Zone d'Ogcheon (Coree du Sud):une chain intraplaque né de ta fermeture au Silurien supérieurDevonien inferrieur, d'un rift cambro-silurien, C.R.Acad, Sci. Paris, II, 310, 59-65, 1990.

Cluzel, D., and J.P. Cadet, La zone d'Ogcheon (Corée du Sud): un rift cambro-ordovicien, C. R. Acad. Sci. Paris, II, 308, 1099.1104, 1989

Cluzel, D., H. Lapierte, and J.P. Cadeh, Mise en évidence d'un magmatisme de rift dans le Palḱzol'que inférieur de la zone
d'Ogcheon (Corée du Sud), CR. Acad. Sci. Paris, II, 308, d'Ogcheon (Corée

Cluzcl, D., J.P. Cadet, and H. Lapierre, Geodynamics of the Ogcheon Belt (South Korea), Teclonophysics, 183,41-56,

Cluzel, D., BJ. Lee, and J.P. Cadet, Indosinian ducule dexural fault system and synkinemate plutonism in the southwest phystcs, (1991, in

Cobbold, $P$., and H. Quinquis, Development of sheath folds in shear regimes, J. Siruct. Geol., 2, 119-126, 1980.

(Eds.), Shear criteria in rocks. J. Struct. Geol., Spec. Issue, 9. 178 pp., 1987.

9, 178 pp., 1987. .

Soc. Spec. Publ , London, 19, 415 pp., 1986.

Emst, W.G., R. Cao, and J. Jiang. Reconnaissance study of Precambrian metamorphic rocks, northeastem Sinokorean
shield, People's Republic of China. Geol Soc. Am. Bull., Jo0, 692-701, 1988.

Geological Society of Korea, The Geological Invesugation Cops of the Taebaeksan Region, Geologic allas of Taebaeksan Region (11 sheets), Geol. Soc. of Korea, Ed.,

Gracciansky de, P.C., G. Dardeau, M. Lemoine, and P. Tricart, De la distension a la compression, linversion structurale dans les Alpes, Bull. Soc. Geol. Fr., 8, 779-785, 1988.

Henderson, J.R., Structural analysis of sheath folds with hornzontal $X$-axes, northeast Canada. J. Struct, Geol., 3, 203 210, 1981 .

Hong. Y.K., Geochemistry of gamet-broute mineral pairs in the H wanggangni area, Korea, J. Geol. Soc. Korea, 20(2). 115-126, 1984

Hong, S.H., and W C. Choi, Explanatory notice of the 1/50,000 geologic map of Korea. Geumsan sheet. 34 pp. Korea Inst. of Energy and Res. Ed.. Seoul, 1978.

Hong, Y.K., and T.Y. Choi, K-Ar ages on biolites of the Proterozoic Buncheon and Hongiesa granilic rocks in the NE part of the Sobaeksan massir, J. Koreon Inst. Min. Geol. 19, 147-151, 1986.
Hsiu, KJ., Q.C. Wang, J.L. Li, D. Zhou, and S. Shu, Tectonic evolution of Qinling mountains, China, Eclogae

Hsu, K.J., J. Li, H. Chen, Q. Wang. S. Sun, and A.M.C. Sengor, Tectonics of South China : Key to understanding Huang. T.K., An outline of tectonic characterisucs of Chna, Eclogae Geoi. Helvet, $71,611-635,1978$.

Inoue, K., Geology and Mineral Ressources of Korea, $J$.

Geogr. Tokyo, 19, 1907.

Kang P.C., and K.H. Chi, Sudy on the geological suructure of Ogeheon system using remolely sensed data Rep. 8, pp. 1980.

Kang P.C., MJ. Choo, K.H. Chi, and J.H. Baek, Study on geologic structure of Daejon-Samrye area using remotely sensed data. Rep. II, pp. 45-74, Korea Institure Geosc, and Min. Resour., Seoul, 1981 .

Kang. P.C.. MJ. Choo, K.H. Ch1, and Y.S. Chor, A study of strucure on the Mungycong coalield using remotely sensed data, Rept. 86-7, pp. 93-127, Korea Inst. of Energy and dala, Rept. 86-7, pp.

Kum, J.H., Caledonuan Ogcheon orogeny of Korea with special relerence to the Ogcheon uraniferous marine black slate Ph.D. thesis, Tokyo University, 208 pp., 1987.

$\mathrm{Kim}$, J.H., Middle Palcozoic isotopic ages of Ogcheon Group in Korea and their significance (abstract), Int. Geol, Congr. $28 t h, 2,103,1989$.

Kim, OJ., Geology and tectonics of the mid-Central region of South Korea, J. Korean Inst. Min Geol., 2, 225-230, 1970 KIm, OJ., Study on the intrusion epochs of younger granttes and their bearing to orogentes in

Inst. Min. Geol., 4, 1-9, 1971.

Kim, OJ., Granite and tectonics in South

Kim, OJ., and K.H. Kim, Petrochemical study on the basic rocks of the Ogcheon zone, J. Korean Inst. Min. Geol., 9. 13-26, 1976

Kım, O.J., K.D. Mın, and H.K. Kım, Geology and mineral resources of the Ogcheon zone - The boundary between the Ogcheon and Joseon systems in the South of Jecheon, and the geology in its

Kim, $S$ H., Micropaleontology of the Kounri formation of the geheon group, M.Sc Thesis, 29 pp., Yonsei Unıv. Scoul, Korea, 1986

Klimetz, MP., Speculations on the Mesozoic plate tectonic evolution of eastern China, Tecionics, 2, 139-166, 1983

Klimetz, M.P., The Mesozoic stratigraphic terranes and accreconnary heritage of southeastem mainland Asia, Geodyn. Ser., vol. 19, edited by E. C. Leitch and E. Scheibner, pp. 221-234, AGU, Washington D.C., 1987.

Kobayashi T., Geology of South Korea, 293 pp., Tokyo University Press, Tokyo, 1953.

Kobayashi, T., Stratigraphy of the Chosen group in Korea and South Mandchuna and its relations to the CambroOrdovician faunas of other areas, J. Fac. Sci. Univ. Tokyo. Japan, Sect. 2, 209-311, 1966.

Lee, B.J., and D. Cluzel, The unconformity at the base of the middle Carboniferous Pyeongan group in the Ogcheon Bel (South Korea) and its tectonic significance, paper presented at Int. Symposium on Geodynamic Evolution

Eurasian Margin, Paris, Sept. 13-20th, 1988. formatuve processes in Ogcheon terrain around Ogcheon tormauve processes in Ogcheon terrain around Ogcheon Min. Geol., 16, 111-123, 1983

Lee, C.N., Principal characteristics of geoce

Le, D.S. An ophiolite suite in the Ogcheon geosynclinal zone, Korea (abstract), Int Geol. Congr., 26th, 1, 61, 1980. Lee, D.S. (Ed.), Geology of Koreo, 514 pp., Geological Sociely of Korea, Kyohak S.A. publ. Seoul, 1987.

Lee, D.S., K.H. Chang, and H.Y. Lee, Discovery of Archaeocyatha from Hyangsangni dolomile formation of the 191-197, 1972.

Lee, H.Y., Discovery of Silurian conodont fauna from South Korea, J. Geol. Soc. Korea, 6, 114-123, 1980.

Lee, H.Y., M.S. Lee, and S.H. Um, Geochemistry of amphıbolites in the Hwanggangn

Lee, J.H., Geologic age of the Hwanggangni formation, $M$. Sc. Thesis, 46 pp., Yonsel Univ., Seoul, Korea, 1987.

Lee, J.H., H.Y. Lee, K.M. Yu, and B.S. Lee, Discovery of microfossils from limestone pebbles of the Hwanggagri Korea. 25, 1-15, 1989 .

Lee, M.S., Geochemistry of amphibolites from the Ogcheon belt and its application to the tectonic setting of the Korean Peninsula, paper presented as Int. Symposium on Geodynamic evolution of Eastern Eurasian margin". Parts. Sept 13-20ih, 1988 .
Lee ,S.M., S. Hidemiko, and S.H. Um, Geochemistry of amphibolites from the Ogchaon belt and tectonic sellıng of the Korean pennsula (abstact), Oflolin, 23,369, 1982 Lee, Y.J. and KIm H.S., Structural analysis of the Okch'on
group ts the Hwanggangnı area, Korea, J. Geol Soc Koreo group in the Hwanggangn! area,

Mallauer, M., P Maule, J. Malavieılle, P. Tapponner, H. Malusky, Z.Q. Xu, Y.L. LU, and Y.Q. Tans. Tecionics of the Qinling belt: buld-up and evolucion of eastem Asia, the Qinling belt: buld-up and

Miyashiro, A., Teclonics and petrologic aspects of Asia, Mem

Geol. Soc China 4, 1-31, 1981.
Proshiro, A., Teclonics and

Na, K.C., Stratigraphical correlation of metamorphic rocks of Precambrian in China, Korea and Japan, Mem. 1986-2, pp 73-86. Scoul Nat. Univ , Korea, 1986.

$\mathrm{Na}$, K.C., Metabasic rocks in the southeastern Ogcheon zone, Korea, 1990, IGCP proj. 224, United Nations Educ., Sci., and Culc Organ., Paris, in Pre-Jurassic Evolution of

Eastem Asia, vol. 6, pp. 207-208, 1990.

Nakamura, S., Chuseihoku (Chuncheon- buk Do), Min. Res.

Korea, 8, 1923

icolas, A., and F. Boudier, Kinematic interpretation of folds in alp

Oh, C.H., Géochimie minérale et organique et métallogénie du gisement uranifere de Goesan, bassin d'Ogcheon (Corre), 1986.

Reedman, A.., and D.H. Hwang, A report on Samhan Janggun mine, Rep. Geol. Miner. Explor.. Seoul, 3, part 2,1975 .

Reedman, A.J., and S.H. Um, Geology of Korea, 139 pp., 1975.

Reedman, AJ., CJ.N. Fletcher, R.B. Evans, D.R. Workman K.S. Yoon, H.S. Rhyu, S.H. Jeon, and Park J.N. Geological, geophysical and geochemical investigations in the Hwangangni area, Chungcheongbukdo. Rep. Geol. Miner. Explor.. Seoul, part 2, 1-119, 1973.

Schoneveld C., A study of some typical inclusion patern in strongly paracrystallinc rotated garnets, in Fabrics, Microstructu-res and microlectonics", edited by P.F
Williams, HJ. Zwart and RJ. Lisle, Tecionophysics, Spec. Issue, 39, 1-3, 1977

Sengor, A M.C., East Asian tectonic collage, Noture, 318, 16 17,1985

Simpson, C. and S.M. Schmid, An evaluation of the cnieria to deduce the sense of movement in sheared rocks, Geol. Soc. Am. Bull. 94, 1281-1288, 1983.

Song, M., and J.H. Kim. A geotecionic study of the Korean peninsula: geological stucuclures of Chongpung area, $J$. Geol. Soc. Korea, 24, 450-463, 1988

Wang, HZ., Y.L. Lu, and Z.G. Zhou. Tectonic developmen of the continental margins on both sides of the Qinling marine realm, Acia Geol. Sin., 3, 270-280, 1982.

Xu, J.W., G. Zhu, W.X. Tong, K.R. Cui, and Q. Lin, Formation and evolution of the Tancheng-Lujiang wrench fault system: a major shear system to the northwest of Pacific Ocean, Tectonophysics, 134, 273-310, 1987.

Xu, Z.Q. Y.L. Lu, Y.Q. Tang, M. Mattauer, P. Matle, J.
Malavieille, and P. Tapponnier, Deformation characteristic Malavieile, and P. Tapponnier, Deformation characteristics (in Chinese with english abstract), Acta Geol. Sin., 60, 237-247, 1986.

Yanai, S., B.S. Park, and S. Oloh, The Honam shear zone (South Korea): deformation and tectonic umplication in the Far East, Sci. Pap. Coll. Arts Sci., Univ. Tokyo, 35(2).

Yang, Z., Y.Q. Cheng, and H.Z. Wang, The Geology of China, Oxford Monogr. Geol. Geophys Ser., vol. 3, 303 pD. Clarendon, Oxford, 1986.

Yun, S.H., K-Ar ages of micas from Precambrian and Phanerozolc rocks in northeastern part of the Republic of Korea, Schwetz. Mineral. Petrogr. Mutt , 63, 295-300,1983. Zhang, Z.M., J.G. Liou and R.G. Coleman, An oulline of plate tecto 1984

Ziegler, P.A., Northwestern Europe: Tectonics and basin

J.P. Cader, CNRS URA ñ 1315, Département de Geotectonique, Université P. et M. Curie, 4 pl. Jussieu, 75252 Paris Cedex 05, France.

D. Clurel, CNRS URA n ${ }^{\circ}$ 1366, Laboratoire de Géologie Stmcturale, Université d'Orléans, BP 6759, 45067 Orléans

Cedex 02, France. Ecole Normale Superieure, 24 rue Lhomond, 75231 Paris, France.

(Received April 24, 1990 revised January 15, 1991; 